\title{
An appraisal of respiratory system compliance in mechanically ventilated covid-19 patients
}

\author{
Gianluigi Li Bassi ${ }^{1,2,3,4,5,6^{*}+}$ D, Jacky Y. Suen ${ }^{1,2+}$, Heidi J. Dalton ${ }^{7}$, Nicole White ${ }^{32}$, Sally Shrapnel ${ }^{2}$, \\ Jonathon P. Fanning 1,2,6, Benoit Liquet ${ }^{2,8,9}$, Samuel Hinton², Aapeli Vuorinen², Gareth Booth², \\ Jonathan E. Millar ${ }^{10,11}$, Simon Forsyth², Mauro Panigada ${ }^{12}$, John Laffey ${ }^{13}$, Daniel Brodie ${ }^{14}$, Eddy Fan 15,16,17,18, \\ Antoni Torres ${ }^{3,19}$, Davide Chiumello ${ }^{17,21}$, Amanda Corley ${ }^{1,2}$, Alyaa Elhazmi22, Carol Hodgson ${ }^{19,20}$, Shingo Ichiba ${ }^{26}$, \\ Carlos Luna ${ }^{27}$, Srinivas Murthy ${ }^{28}$, Alistair Nichol ${ }^{24,25}$, Pauline Yeung $\mathrm{Ng}^{29}$, Mark Ogino ${ }^{30}$, Antonio Pesenti ${ }^{12,21}$, \\ Huynh Trung Trieu ${ }^{31}$ and John F. Fraser 1,2,3,4,5, on behalf of the COVID-19 Critical Care Consortium
}

\begin{abstract}
Background: Heterogeneous respiratory system static compliance $\left(C_{R S}\right)$ values and levels of hypoxemia in patients with novel coronavirus disease (COVID-19) requiring mechanical ventilation have been reported in previous smallcase series or studies conducted at a national level.
\end{abstract}

Methods: We designed a retrospective observational cohort study with rapid data gathering from the international COVID-19 Critical Care Consortium study to comprehensively describe $C_{R S}$ - calculated as: tidal volume/[airway plateau pressure-positive end-expiratory pressure (PEEP)] —and its association with ventilatory management and outcomes of COVID-19 patients on mechanical ventilation (MV), admitted to intensive care units (ICU) worldwide.

Results: We studied 745 patients from 22 countries, who required admission to the ICU and MV from January 14 to December 31, 2020, and presented at least one value of $C_{R S}$ within the first seven days of MV. Median (IQR) age was 62 (52-71), patients were predominantly males (68\%) and from Europe/North and South America (88\%). $C_{R S}$, within $48 \mathrm{~h}$ from endotracheal intubation, was available in 649 patients and was neither associated with the duration from onset of symptoms to commencement of $\mathrm{MV}(p=0.417)$ nor with $\mathrm{PaO}_{2} / \mathrm{FiO}_{2}(p=0.100)$. Females presented lower $C_{\mathrm{RS}}$ than males (95\% $\mathrm{Cl}$ of $C_{\mathrm{RS}}$ difference between females-males: -11.8 to $-7.4 \mathrm{~mL} / \mathrm{CmH}_{2} \mathrm{O} p<0.001$ ), and although females presented higher body mass index (BMI), association of BMI with $C_{R S}$ was marginal $(p=0.139)$. Ventilatory management varied across $C_{R S}$ range, resulting in a significant association between $C_{R S}$ and driving pressure (estimated decrease $-0.31 \mathrm{cmH}_{2} \mathrm{O} / \mathrm{L}$ per $\mathrm{mL} / \mathrm{cmH}_{2} 0$ of $C_{\mathrm{RS}}, 95 \% \mathrm{Cl}-0.48$ to $-0.14, p<0.001$ ). Overall, 28-day ICU mortality, accounting for the competing risk of being discharged within the period, was 35.6\% (SE 1.7). Cox proportional hazard analysis demonstrated that $C_{R S}\left(+10 \mathrm{~mL} / \mathrm{cm} \mathrm{H}_{2} \mathrm{O}\right)$ was only associated with being discharge from the ICU within 28 days (HR $1.14,95 \% \mathrm{Cl} 1.02-1.28, p=0.018)$.

\footnotetext{
*Correspondence: g.libassi@uq.edu.au

${ }^{\dagger}$ Gianluigi Li Bassi and Jacky Y. Suen have equally contributed to this work

${ }^{1}$ Critical Care Research Group, The Prince Charles Hospital, Chermside, Australia

Full list of author information is available at the end of the article
}

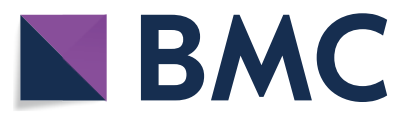

(c) The Author(s) 2021. Open Access This article is licensed under a Creative Commons Attribution 4.0 International License, which permits use, sharing, adaptation, distribution and reproduction in any medium or format, as long as you give appropriate credit to the original author(s) and the source, provide a link to the Creative Commons licence, and indicate if changes were made. The images or other third party material in this article are included in the article's Creative Commons licence, unless indicated otherwise in a credit line to the material. If material is not included in the article's Creative Commons licence and your intended use is not permitted by statutory regulation or exceeds the permitted use, you will need to obtain permission directly from the copyright holder. To view a copy of this licence, visit http://creativecommons.org/licenses/by/4.0/. The Creative Commons Public Domain Dedication waiver (http://creativeco mmons.org/publicdomain/zero/1.0/) applies to the data made available in this article, unless otherwise stated in a credit line to the data. 
Conclusions: This multicentre report provides a comprehensive account of $C_{R S}$ in COVID-19 patients on MV. $C_{R S}$ measured within $48 \mathrm{~h}$ from commencement of MV has marginal predictive value for 28-day mortality, but was associated with being discharged from ICU within the same period. Trial documentation: Available at https://www.covidcritical.com/study.

Trial registration: ACTRN12620000421932.

Keywords: Mechanical ventilation, Compliance, ARDS, COVID-19, SARS-CoV-2

\section{Background}

Millions of people have been infected by SARS-CoV-2 worldwide, and many of those have been hospitalized for respiratory complications associated with coronavirus disease-2019 (COVID-19). Many of those COVID-19 hospitalised patients have received mechanical ventilation (MV), due to the development of acute hypoxemic respiratory failure and acute respiratory distress syndrome (ARDS) [1-4]. To date, several landmark studies [5-8] have improved our understanding of COVID-19 pulmonary pathophysiology, but pulmonary derangement in COVID-19 and appropriate ventilatory management remains incompletely characterized.

Earlier reports on the pulmonary pathophysiology of COVID-19 patients reported conflicting results and extreme heterogeneity in levels of pulmonary shunting, static respiratory system compliance $\left(C_{\mathrm{RS}}\right),[9-12]$ and substantial heterogeneity in lung recruitability $[13,14]$. Adding further to the controversy over $C_{\mathrm{RS}}$ in COVID-19 patients, Grasselli and collaborators [7] have compared findings from an Italian repository of COVID-19 ARDS with previous ARDS cases of different etiologies. They found statistically significant higher $C_{\mathrm{RS}}$ in patients with COVID-19 ARDS. In addition, they found that patients who presented with lower $C_{\mathrm{RS}}$ and higher $\mathrm{D}$-dimer values had the greatest mortality risk. In line with these figures, in a small-case series, Chiumello and collaborators found that COVID-19 patients presented higher $C_{\mathrm{RS}}$ levels in comparison with patients with ARDS from other etiologies and matched levels of hypoxemia [12]. Regrettably, those previous reports did not provide any information on how $C_{\mathrm{RS}}$ progressed beyond a punctual assessment during the period of MV. In contrast, in another landmark study by Ferrando et al. [6], $C_{\mathrm{RS}}$ figures from a Spanish database were very similar to previously published cohorts of ARDS patients. The authors also found that intensive care unit (ICU) discharge and mortality were not influenced by the initial levels of $C_{\mathrm{RS}}$.

In a pandemic caused by a novel virus, access to international data is vital, because it may help account for differences in populations, access to medical care, equipment and critical variations in clinical managements among countries. Thus, analysis of international repositories improves the overall understanding of a novel disease and helps establishing best practices to enhance outcome. One example of how single-center or single-country studies can influence medical care early in a pandemic, before being contradicted by subsequent international findings is the issue of $C_{\mathrm{RS}}$. Indeed, as this parameter can be markedly impacted by fine variations in ventilatory management, extrapolations from monocenter or single-country studies may be challenging. In early January 2020, the COVID-19 Critical Care Consortium incorporating the ExtraCorporeal Membrane Oxygenation for 2019 novel Coronavirus Acute Respiratory Disease (COVID-19-CCC/ECMOCARD) group was founded to investigate patients presenting to ICUs worldwide.

Here, we present a comprehensive appraisal of $C_{\mathrm{RS}}$ in mechanically ventilated COVID-19 patients enrolled into the COVID-19-CCC/ECMOCARD international study, in order to understand the dynamics of $C_{\mathrm{RS}}$ during the first week of mechanical ventilation and its potential impact on patient outcomes.

\section{Materials and methods}

\section{Study design and oversight}

The COVID-19-CCC/ECMOCARD is an international, multicentre, cohort observational study ongoing in 351 hospitals across 53 countries. The full study protocol is available elsewhere [15]. To summarize, participating hospitals obtained local ethics committee approval and a waiver of informed consent was granted in all cases. ISARIC/SPRINT-SARI data collection began at admission to hospital, while data collection for the COVID-19CCC observational study commenced at admission to the ICU. De-identified patient data were collected retrospectively and stored via the REDCap electronic data capture tool, hosted at the University of Oxford, United Kingdom or Monash University, Melbourne, Australia.

\section{Study population}

We reviewed data of all patients admitted to the ICU at a COVID-19-CCC collaborating site, from January 14 through September 30, 2020, with a clinically suspected or laboratory confirmed diagnosis of SARS$\mathrm{CoV}-2$ infection, through naso-pharyngeal swab for realtime PCR SARS-CoV-2 detection. Of note, suspicion 
of SARS-CoV-2 infection was based on symptoms and onset of infection and was confirmed by the clinician when COVID-19 infection was the most likely cause of the symptoms experienced. Patients excluded were those under the age of 15 years or admitted to an ICU for other reasons. We focused our analysis on patients on controlled MV and with a computed $C_{\mathrm{RS}}$ value within $48 \mathrm{~h}$ of MV commencement.

\section{Definitions and pulmonary mechanics computations}

$C_{\mathrm{RS}}$ was calculated as: tidal volume $(\mathrm{mL}) /[$ (airway plateau pressure-PEEP $\left.\left.\left(\mathrm{cmH}_{2} \mathrm{O}\right)\right)\right]$. Of note, we provided to data collectors a detailed data dictionary, with instructions on how to collect airway plateau pressure values, via an inspiratory pause of approximately $3 \mathrm{~s}$. We computed $C_{\mathrm{RS}}$ using the first measured tidal volume, airway plateau pressure and PEEP values, within $48 \mathrm{~h}$ of MV commencement. In the sub-population of patients on controlled $\mathrm{MV}$, without ECMO support, we analysed key pulmonary variables, such as tidal volume, positive end expiratory pressure (PEEP), static driving pressure, inspiratory fraction of oxygen $\left(\mathrm{FiO}_{2}\right)$, and gas exchange, recorded during routine clinical practice and only. Tidal volume was reported in $\mathrm{mL} / \mathrm{kg}$ of predicted body weight (PBW) [16].

\section{Data collection}

After enrolment, data on demographics, comorbidities, clinical symptoms and laboratory results were collected by clinical and research staff of the participating ICUs in an electronic case report form [15]. Details of respiratory and hemodynamic support, physiological variables, and laboratory results were collected daily. Of note, the worst daily values were preferentially recorded. The duration of MV and ICU stay, and hospital mortality were recorded. Analysis of daily data was restricted to the first seven days from commencement of MV.

\section{Statistical analyses}

Descriptive statistics summarised demographics, clinical signs on ICU admission, ICU management and clinical outcomes for the overall study cohort and subjects with baseline compliance measured within the first $48 \mathrm{~h}$ of controlled MV. Statistics were reported as medians (interquartile range) for continuous variables and numbers (percentage) for categorical variables. Linear regression was applied to summarise associations between baseline compliance with body mass index (BMI) (including interaction between $\mathrm{BMI}$ and sex), days from symptom onset to $\mathrm{MV}$ commencement and $\mathrm{PaO}_{2} / \mathrm{FiO}_{2}$, adjusted for BMI. Linear mixed modelling was used to investigate trends in compliance over time and associations with key respiratory parameters during the first 7 days of controlled MV. Models assumed a linear effect for days and a random intercept per subject to account for repeated measures. Consistent with exploratory analyses, BMI was included as a fixed effect to adjust for potential confounding in the clinical characteristics and management of patients with different BMI. Hypothesis testing was applied to all fixed effects, assuming a 5\% level of statistical significance. Results were summarised graphically with uncertainty in estimated trends represented by $95 \%$ prediction intervals. Expected patient outcomes including length of ICU stay, duration of MV and risk of ICU mortality versus discharge were examined using multi-state modelling [17]. Compared with exploratory analyses of clinical outcomes, the multistate model accounted for ICU discharge and death as competing events and allowed data from all patients to be included, regardless of study follow-up time. The model comprised of four states, to describe patients prior to commencement of MV (non MV), on mechanical ventilation (MV), ICU discharged (Discharge) and mortality (Death). States were presented as percentage and standard error (SE) in the text. Patients extubated before death or discharge were assumed to transition between MV an non-MV states. State transitions were modelled by Cox proportional hazards, with patients censored at last known follow-up, up to 28 days from ICU admission. Follow-up analysis considered Cox proportional hazard regression to examine associations between baseline compliance and competing risks of ICU mortality and discharge, following commencement of MV. Baseline compliance was included as a linear effect, with age, sex, BMI and comorbidities (hypertension, chronic cardiac disease, chronic kidney disease) as additional covariates and adjusted for recruiting centre. A shared frailty term (Gamma distributed) was included to account for residual variation between study sites. Analyses were conducted using $\mathrm{R}$ version 3.6.2 or higher (The R Foundation).

\section{Results}

We studied 745 patients from 22 countries, who required admission to the ICU and MV from January 14 to December 31, 2020, and presented at least one value of $C_{\mathrm{RS}}$ within the first seven days of MV. Among those, 597 (80\%) had laboratory-confirmed diagnosis of SARS-CoV2 infection, while in $148(20 \%)$, infection was clinically suspected. Enrolment rate, since January 2020, is reported in Fig. 1. $C_{\mathrm{RS}}$, within $48 \mathrm{~h}$ from endotracheal intubation, was available in 649 patients (Fig. 2). No association between $C_{\mathrm{RS}}$ and days from onset of symptoms to commencement of MV was found (Fig. 3). Median $C_{\mathrm{RS}}$ (IQR), within the first $48 \mathrm{~h}$ of mechanical ventilation, was $34.1 \mathrm{~mL} / \mathrm{cmH}_{2} \mathrm{O}$ (26.4-44.0) and $\mathrm{PaO}_{2} / \mathrm{FiO}_{2} 113.0 \mathrm{mmHg}$ (84.0-161.3), without any linear association between these parameters. In particular, $16 \%, 46 \%$ and $38 \%$ of the patients presented 


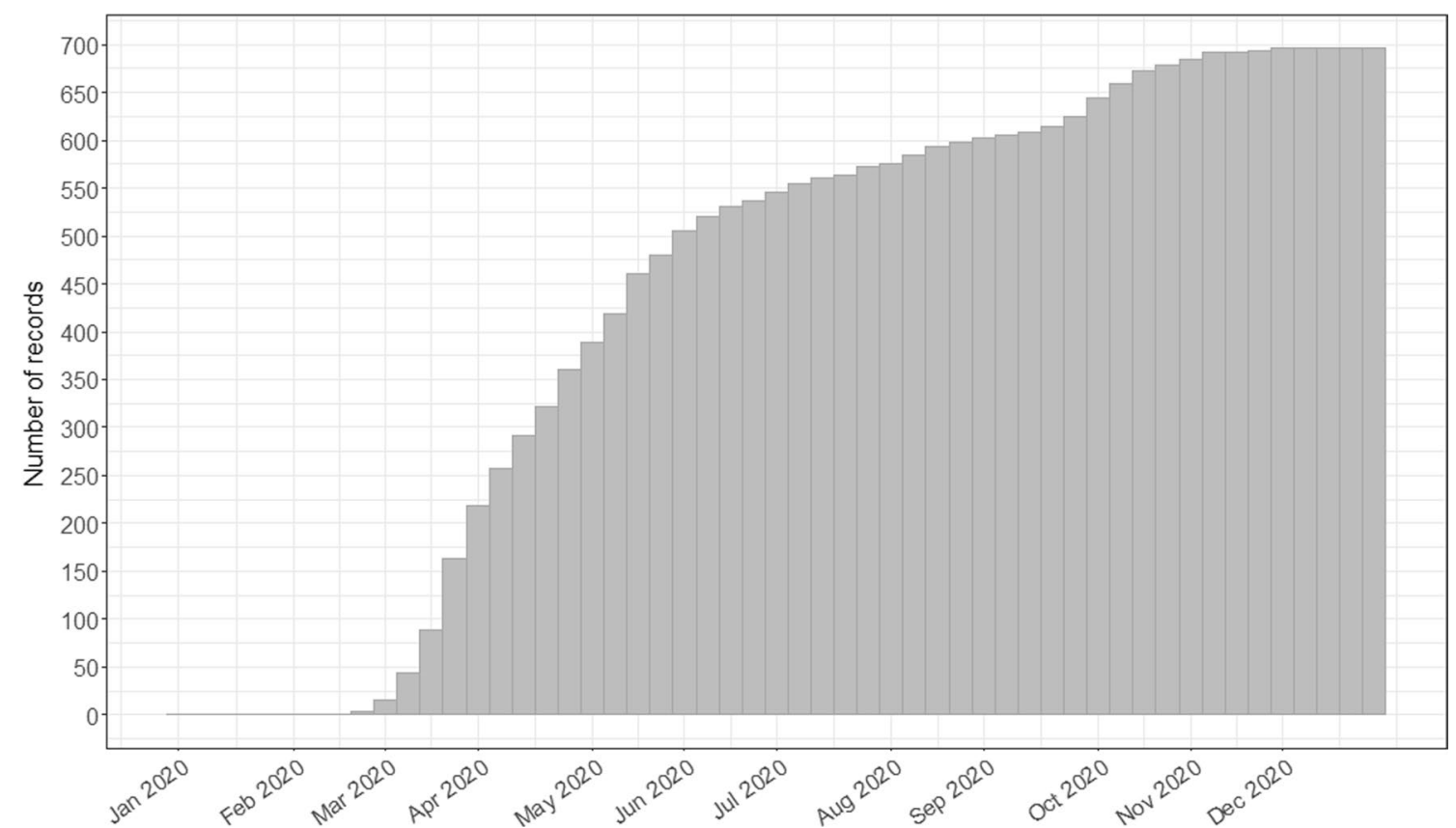

Fig. 1 Patient enrolment rate from January 14 through December 31, 2020

2880 COVID-19 Patients

Admitted to ICU from 147

Recruiting Sites

1052 Excluded

2 Missing age or

58 less than 15 years old

856 no start date of MV recorded

492 MV duration less than 24 hours

\section{COVID-19 Patients on Invasive}

MV for at least 24 hours

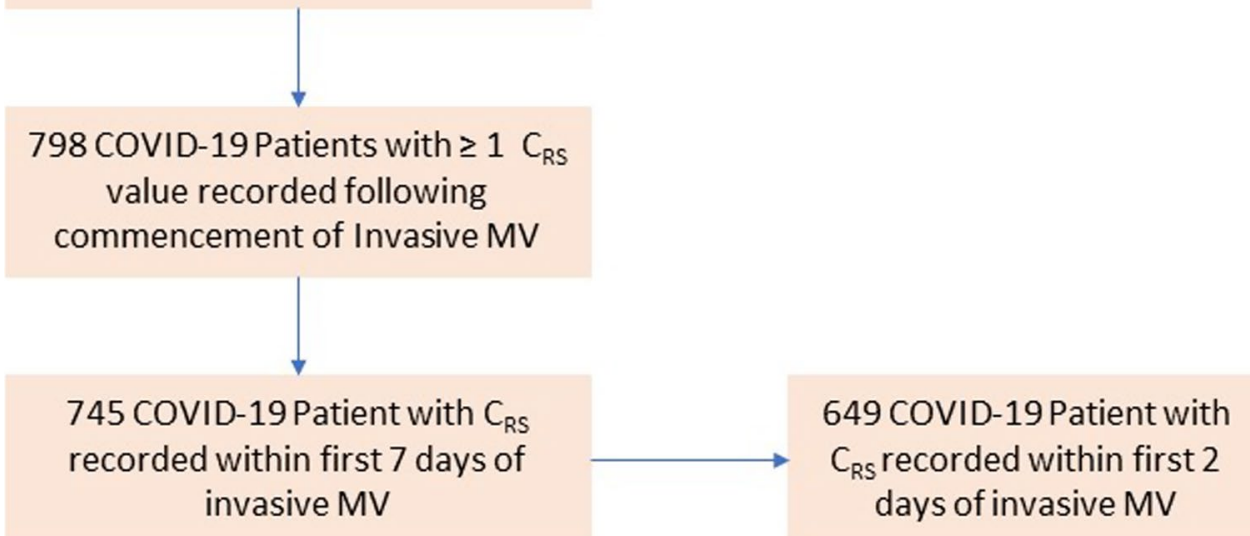

Fig. 2 Patient population flow chart. The analysis of 1505 COVID-19 patients on mechanical ventilation identified 649 patients with static respiratory system compliance within $48 \mathrm{~h}$ from commencement of mechanical ventilation 


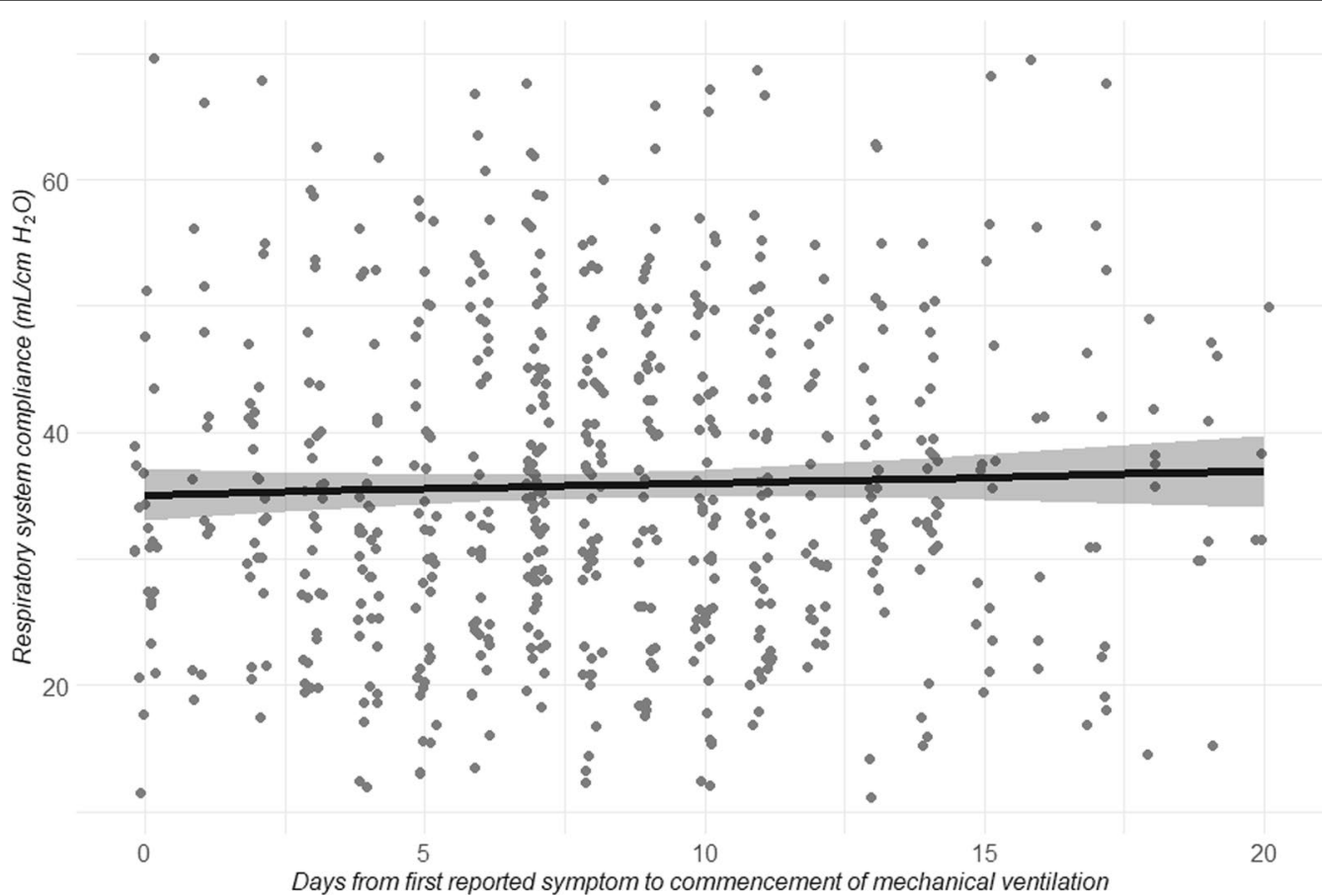

Fig. 3 Linear regression analysis of days from onset of symptoms to commencement of mechanical ventilation and static respiratory system compliance, based on the first measurement obtained within $48 \mathrm{~h}$ from commencement of mechanical ventilation, adjusted for body mass index. Dark black horizontal bar depicts median value, and upper and lower horizontal light black bars show 90th and 10th percentile. Days of onset of symptoms to commencement of mechanical ventilation was not associated with static respiratory system compliance (estimate $0.92 \mathrm{~mL} / \mathrm{cmH}_{2} \mathrm{O}$, $95 \% \mathrm{Cl}-0.31-0.31 p=0.417)$

with mild, moderate or severe hypoxemia, respectively (Fig. 4a). Female sex was associated with a significantly lower $C_{\mathrm{RS}}$ than in males (95\% CI of difference between genders: -11.8 to $-7.4 \mathrm{~mL} / \mathrm{cmH}_{2} \mathrm{O} p<0.001$ ) (Fig. $4 \mathrm{~b}$ ). Females also presented higher body mass index (BMI) (95\% CI of difference between males and females: -1.9 to $-5.5, p<0.001$ ), but as shown in Fig. $5, C_{\mathrm{RS}}$ and BMI were not linearly associated. Our model estimated that $C_{\text {RS }}$ was $37.57 \mathrm{cmH}_{2} \mathrm{O} / \mathrm{mL}$ (95\% CI 36.5-38.6) upon commencement of MV (Fig. 6), with further worsening in the first seven days of MV (estimated decrease -0.31 $\mathrm{cmH}_{2} \mathrm{O} / \mathrm{mL}$ per day, $95 \% \mathrm{CI}-0.48$ to $\left.-0.14, p<0.001\right)$. In addition, as detailed in Fig. $7, \mathrm{PaCO}_{2}$, tidal volume, PEEP, driving pressure and $\mathrm{FiO}_{2}$ significantly varied across the range of $C_{\mathrm{RS}}$, and a significant association was found between inspiratory plateau pressure and $C_{\mathrm{RS}}$ changes (Fig. 8).

Baseline characteristics upon ICU admission, applied interventions and outcomes, are summarized in Table 1.
The most common interventions applied to the study population were use of antibiotics (96\%), neuromuscular blocking agents $(81 \%)$ and prone position $(61 \%)$. The overall hospital mortality of the study population was $40 \%$, and among those patients who died in the hospital or were discharged alive, the median (IQR) duration of MV was 11 days (6-18) and 14 days (8-23), respectively. Overall, 28-day ICU mortality, accounting for competing risks, was 35.6\% (SE 1.7) and estimated 28-day mortality from commencement of MV was 37.1\% (SE 1.7) (Fig. 9b). Cox proportional hazard analysis (Fig. 9c) demonstrated that age (hazard ratio 1.37, 95\% CI 1.19-1.59, $p<0.001)$ and chronic cardiac diseases (HR 1.62, 95\% CI $1.14-2.29, p<0.001$ ) were the only baseline factors associated with 28 -day mortality risk. In addition, age (HR $0.77,95 \%$ CI $0.66-0.83, p<0.001$ ), male sex (HR 0.59, 95\% CI 0.44-0.79, $p<0.001$ ), BMI (HR 0.86, 95\% CI 0.79-0.95, $p=0.003)$ and $C_{\mathrm{RS}}\left(+10 \mathrm{~mL} / \mathrm{cm} \mathrm{H}_{2} \mathrm{O}\right)(\mathrm{HR} 1.14,95 \% \mathrm{CI}$ $1.02-1.28, p=0.018)$ were associated with the chance of being discharge from the ICU within 28 days. 


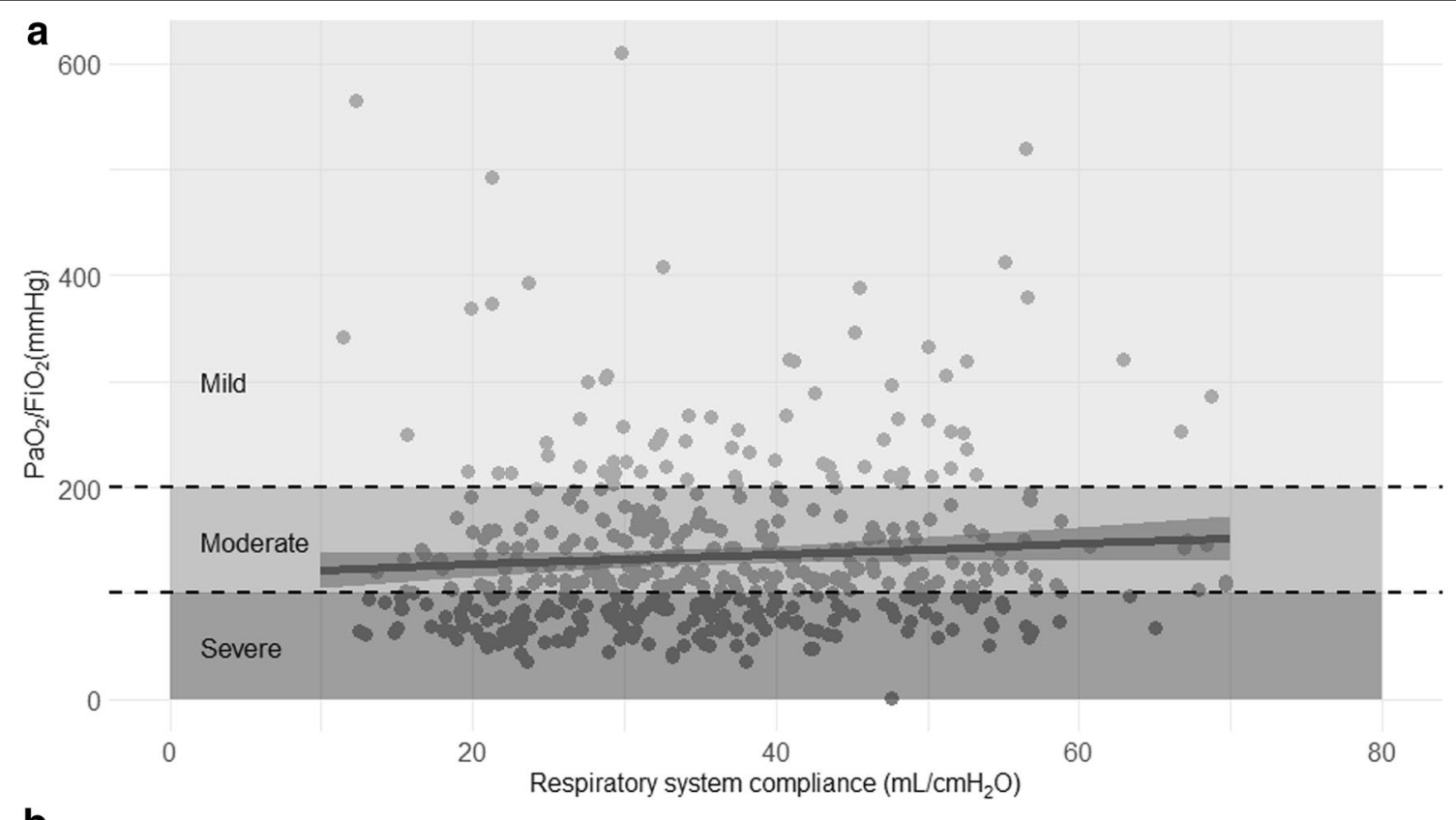

b

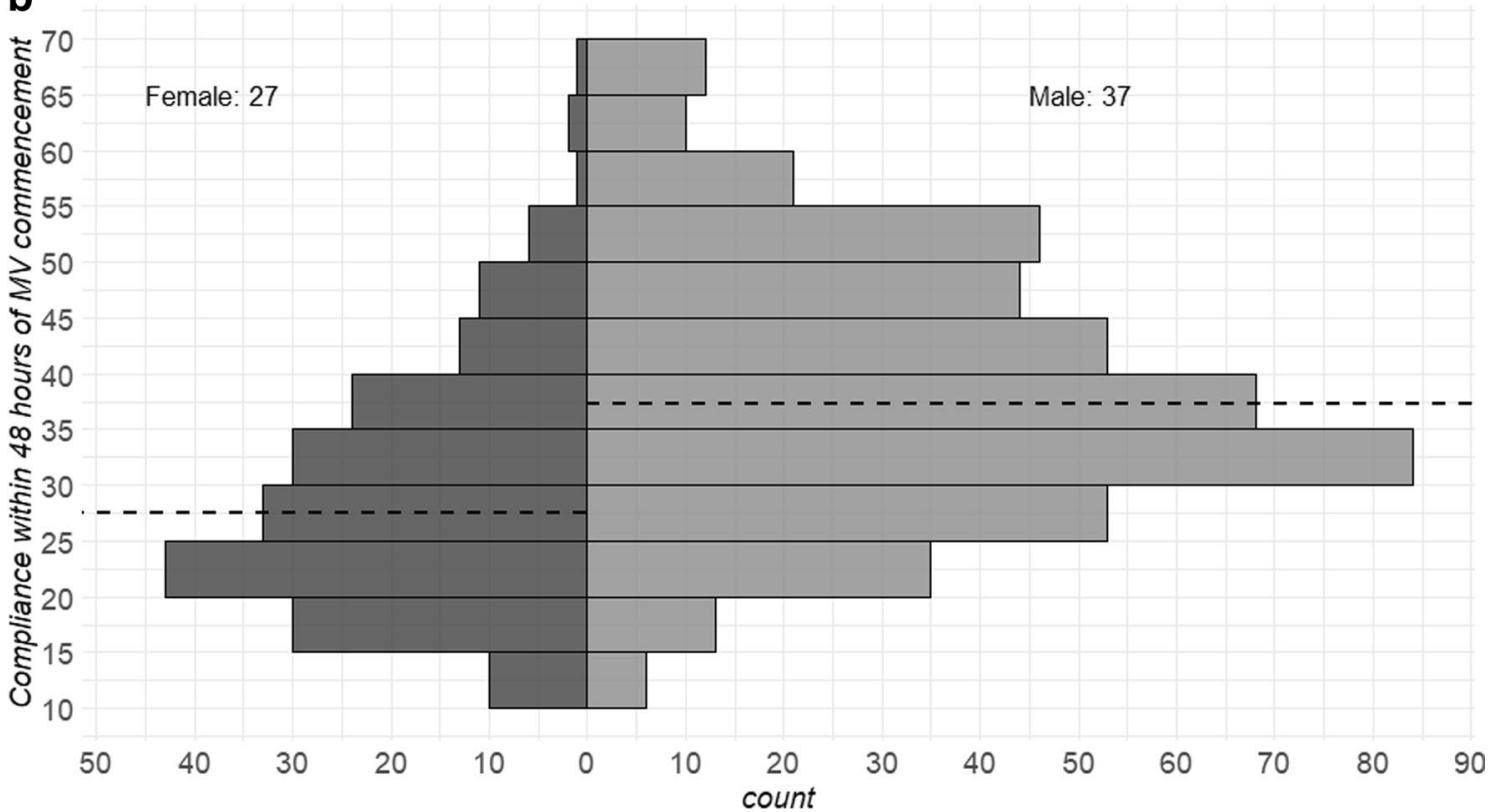

Fig. 4 a Linear regression analysis of arterial partial pressure of oxygen $\left(\mathrm{PaO}_{2} / \mathrm{FiO}_{2}\right)$ and respiratory system compliance $\left(C_{\mathrm{RS}}\right)$, based on the first measurement obtained within $48 \mathrm{~h}$ from commencement of mechanical ventilation, with an interaction of gender and adjusted for body mass index (BMI). No statistically significant association was found between $\mathrm{PaO}_{2} / \mathrm{FiO}_{2}$ and $C_{\mathrm{RS}}$ (estimate $0.49,95 \% \mathrm{Cl}-0.09-1.07 p=0.100$ ). Typical acute respiratory distress syndrome stratification groups [35] (severe, moderate and mild based on levels of hypoxemia) are highlighted in dark, medium and light grey, respectively. $\mathbf{b}$ Static respiratory system compliance $\left(C_{R S}\right)$ distribution by sex, based on the first measurement obtained within $48 \mathrm{~h}$ from commencement of mechanical ventilation. Dashed black lines depict median values for females and males

\section{Discussion}

This large observational report from intensive care units throughout the world found that initial static respiratory system compliance was only associated with hazard of being discharged from the ICU within 28 days. The duration from onset of symptoms to commencement of MV did not influence $C_{\mathrm{RS}}$, and interestingly lower $C_{\mathrm{RS}}$ was found in female patients. In the evaluated population, neuromuscular blocking agents and prone position were commonly applied and ventilatory management 


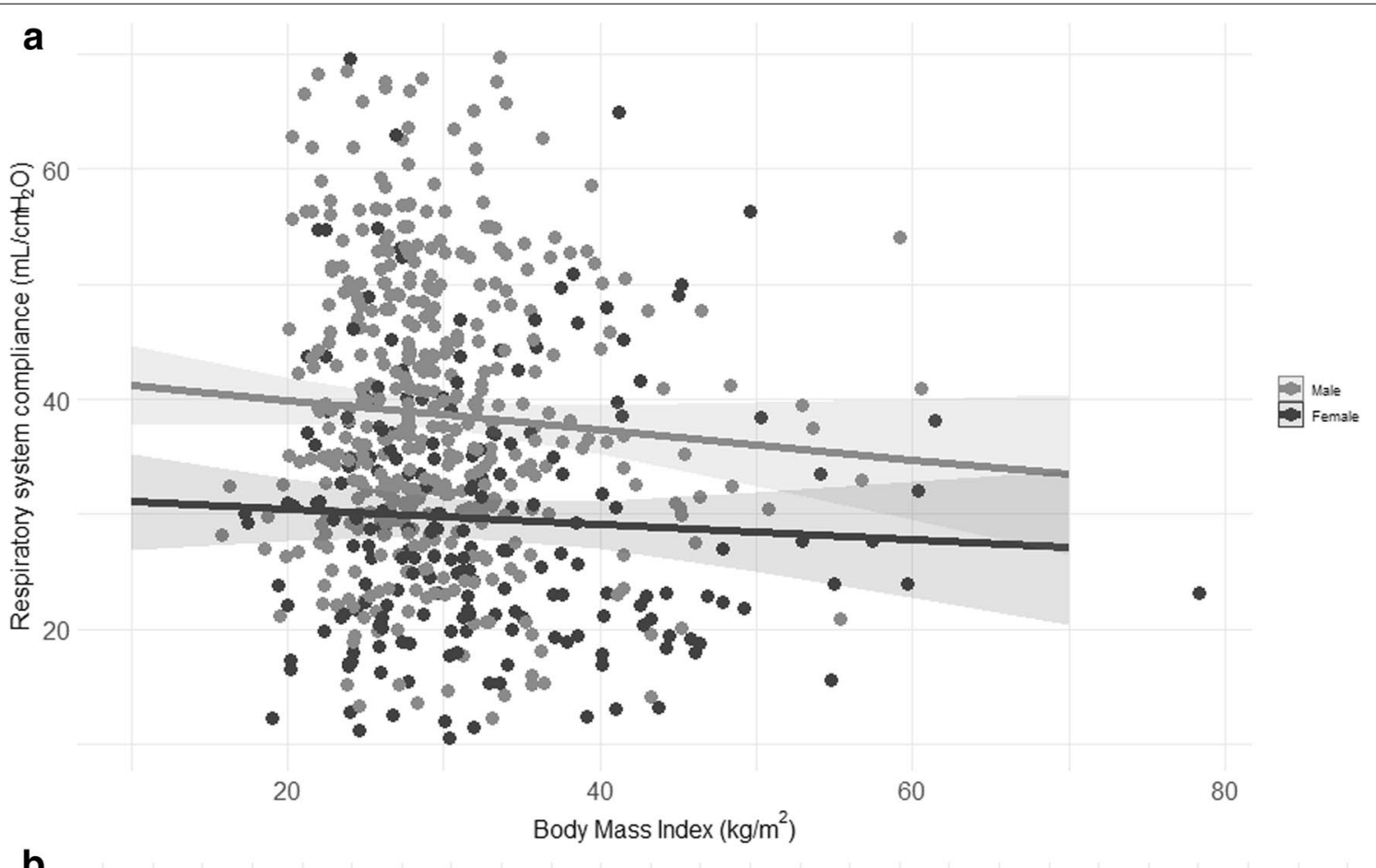

b

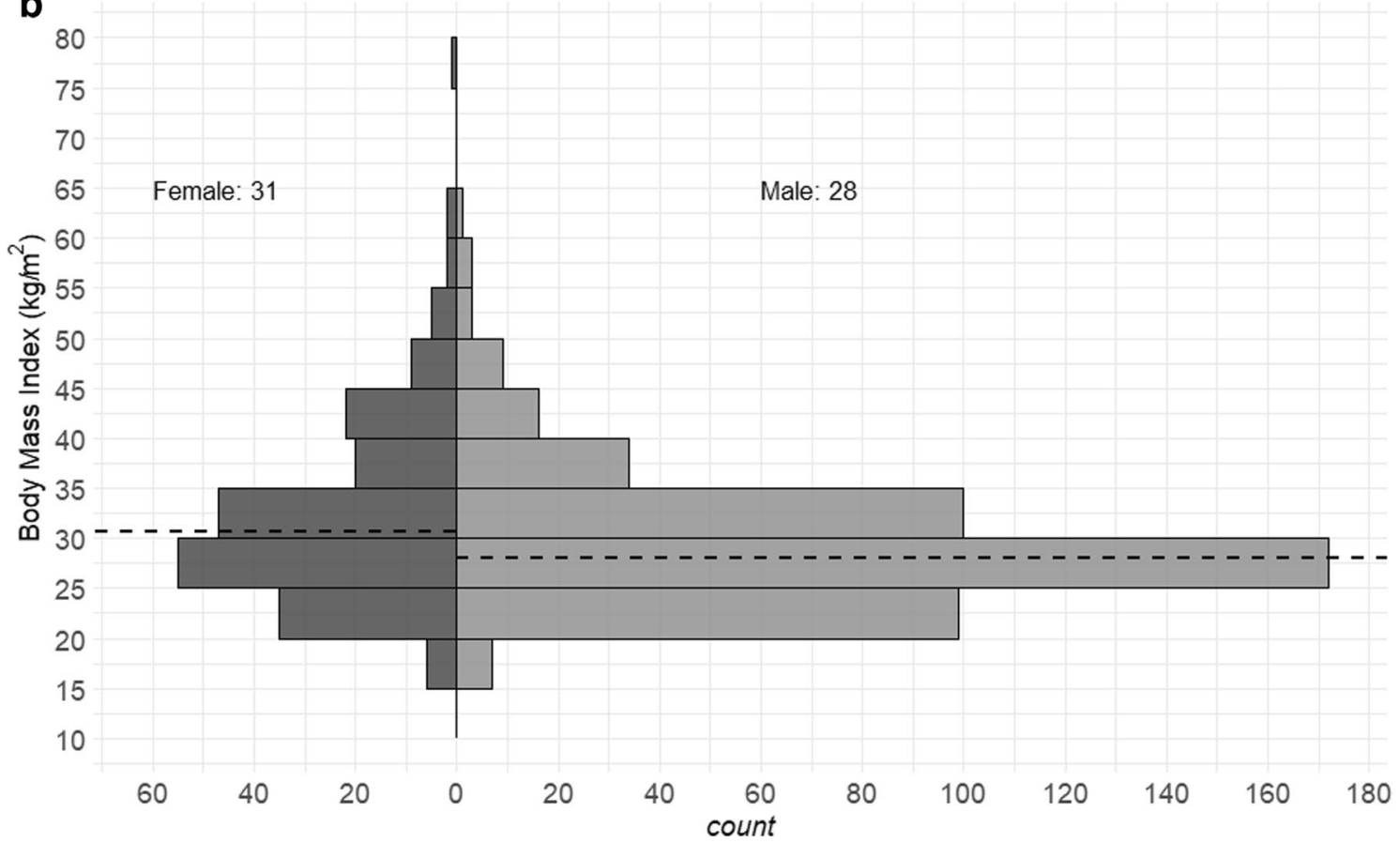

Fig. 5 Linear regression analysis of static respiratory system compliance, based on the first measurement obtained within $48 \mathrm{~h}$ from commencement of mechanical ventilation, and body mass index with an interaction for sex. Per each graph, fitted line of the model is depicted and the upper and lower lines display the 95\% predictive interval. Dark grey dots depict female patients, while light grey dots males. Static respiratory system compliance did not vary according to the body mass index (estimate $-0.12 \mathrm{cmH}_{2} \mathrm{O} / \mathrm{mL}, 95 \% \mathrm{Cl}-0.29$ to $-0.04, p=0.139$ ), but was associated with female sex (estimate $-10.73 \mathrm{cmH}_{2} \mathrm{O} / \mathrm{mL}, 95 \% \mathrm{Cl}-18.54$ to $-2.92, p=0.007$ ) 


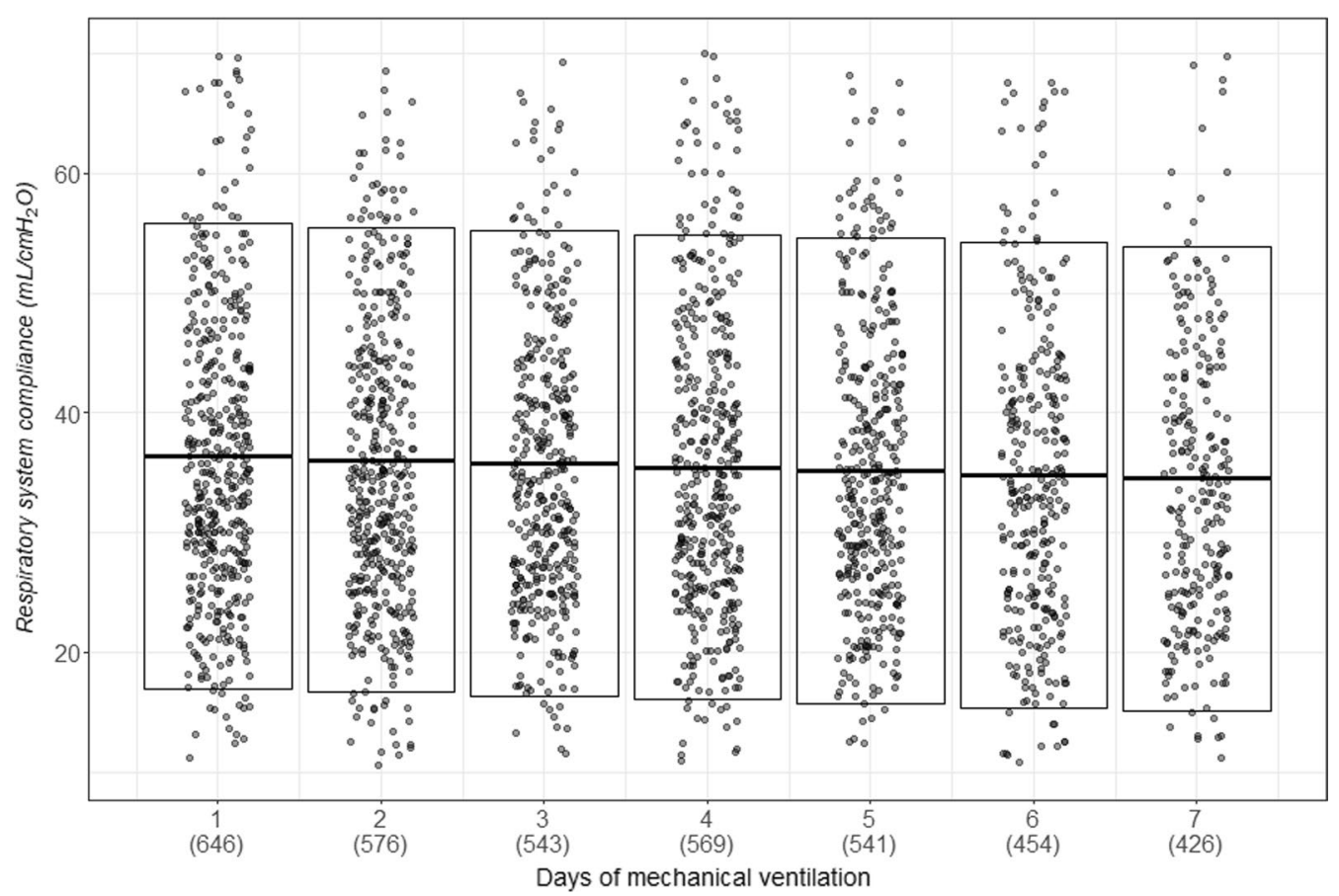

Fig. 6 Static respiratory system compliance dynamics. Evolution of static respiratory system compliance over the first 7 days of mechanical ventilation, adjusted for body mass index. Under each day, the number of analysed patients is reported in parenthesis. Fitted line of the model is depicted, and the upper and lower lines display the $95 \%$ predictive interval. Respiratory system compliance varied during the first seven days of mechanical ventilation (estimate $-0.31 \mathrm{cmH}_{2} \mathrm{O} / \mathrm{mL}, 95 \% \mathrm{Cl}-0.48$ to $0.14, p<0.001$ )

across $C_{\mathrm{RS}}$ levels varied in terms of tidal volume, PEEP and $\mathrm{FiO}_{2}$, throughout the first 7 days of MV.

In comparison with previous reports on ARDS patients without COVID-19 [18], we similarly found that the majority of patients exhibited moderate hypoxemia, even when presented higher $C_{\mathrm{RS}}$. We also noted a larger range of $C_{\mathrm{RS}}$ in line with previous studies [7, 8], but in contrast with values from a larger COVID-19 ARDS series from Spain [6]. Considering that we focused our analysis on static compliance of the respiratory system, without partitioning into the pulmonary and chest wall components $[19,20]$, it is interesting that $C_{\mathrm{RS}}$ was not associated with BMI, suggesting that patients with higher BMI potentially presented also with higher lung compliance. Irrespective, we found lower $C_{\mathrm{RS}}$ in female patients, who also presented higher BMIs. To the best of our knowledge, no studies have systematically investigated the effects of gender/BMI on COVID-19 severity; thus, whether obesity might be a crucial risk factor for ICU admission and mechanical ventilation, specifically in female patients, and its effects on lung compliance should be further explored. We also found that throughout the range of $C_{\mathrm{RS}}$ values, plateau pressure was within what is typically presumed as lung protective ranges [21], but this resulted in potentially harmful driving pressures, specifically for patients with the lowest $C_{\mathrm{RS}}$ values. As many of these patients were obese, this raises the question of whether these modest pressures might have increased the risk of pulmonary derecruitment, or in patients with normal BMI, the resulting driving pressure might have been related to pulmonary overdistention. These factors could have contributed to sustained hypoxemia and impaired lung function throughout the study period. In such circumstances, it is questionable whether MV guided by oesophageal pressure monitoring may have some benefits [22], but more research is needed to corroborate such reasoning.

Phenotypic subsets of COVID-19-associated ARDS have been proposed $[9,13,23-25]$. Recent study has also explored whether $C_{\mathrm{RS}}$-related phenotype patterns existed among patients with ARDS before the COVID-19 pandemic [26]. Various investigators [7, 27], who did not find significant $C_{\mathrm{RS}}$ variability among COVID-19 patients requiring $\mathrm{MV}$, questioned the overall clinical value of $C_{\mathrm{RS}}$ in the COVID-19 population. In a very small case series, Gattinoni et al [9] found an initial $C_{\mathrm{RS}}$ of $50 \mathrm{~mL} /$ $\mathrm{cmH}_{2} \mathrm{O}$, but high levels of shunt fraction that could have explained the resulting severe hypoxemia. In subsequent study, Chiumello and collaborators found higher $C_{\mathrm{RS}}$ in patient with COVID-19 ARDS and ARDS caused by 

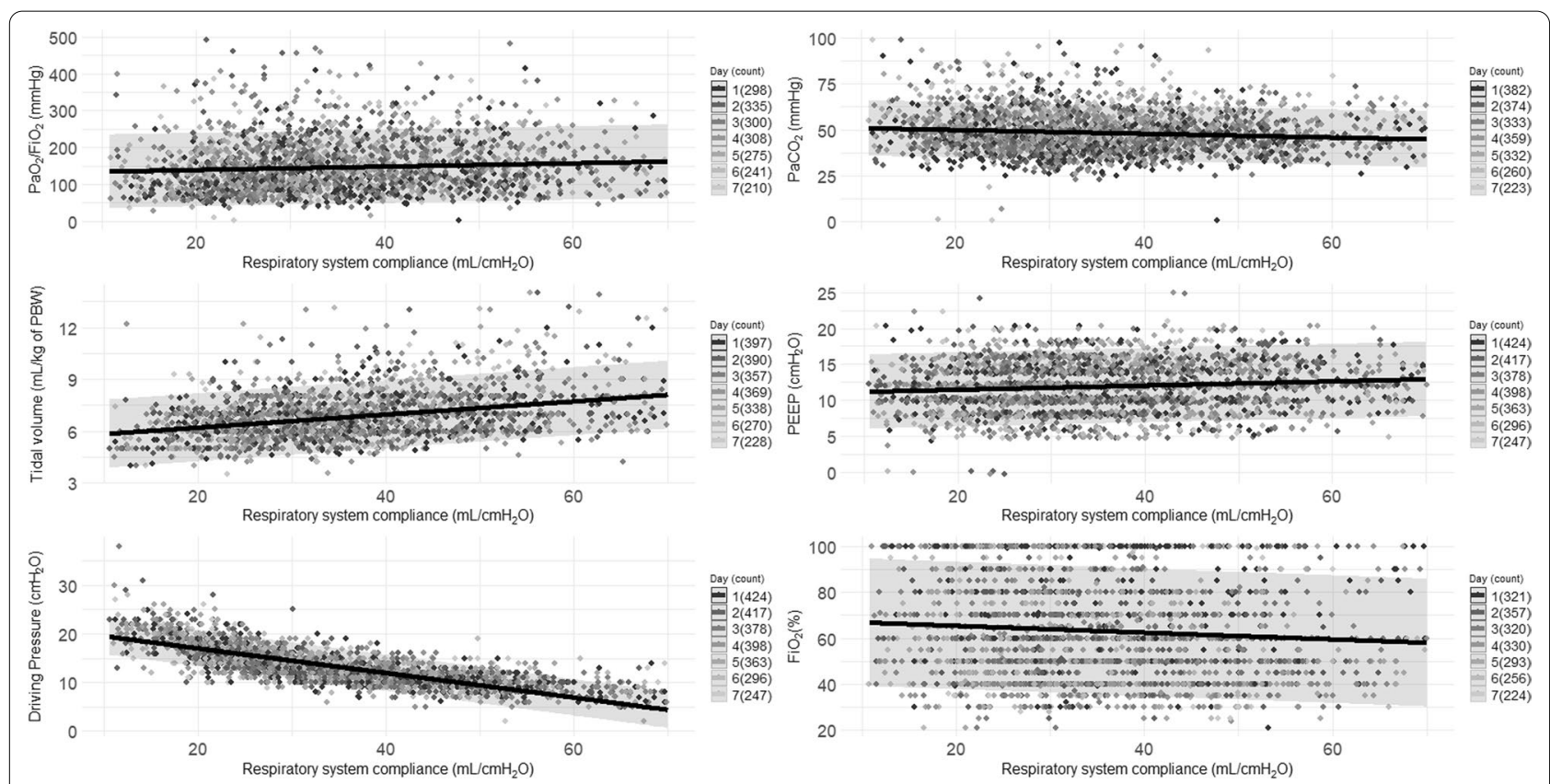

Fig. 7 Linear Mixed model analysis of respiratory system compliance vs. crucial pulmonary variables during the first 7 days of mechanical ventilation (grey-scale coded bar for day 1 through 7 is reported on the right section of each graph and in parenthesis is reported the number of analysed patients). Per each graph, fitted line of the model is depicted and the upper and lower lines display the 95\% predictive interval. All analyses are adjusted for body mass index. Static compliance of respiratory system was found to be associated with $\mathrm{PaCO}_{2}$ (estimated decrease $-0.11 \mathrm{mmHg}, 95 \% \mathrm{Cl}-0.15$ to $-0.06, p<0.001$ ), tidal volume (estimated increase $0.04 \mathrm{~mL} / \mathrm{Kg}$ of predicted body weight per day, $95 \% \mathrm{Cl} 0.03-0.04$, $p<0.001$ ), PEEP (estimated increase $-0.03 \mathrm{cmH}_{2} \mathrm{O}, 95 \% \mathrm{Cl} 0.02-0.04, p<0.001$ ), driving pressure (estimated decrease $-0.31 \mathrm{~cm} \mathrm{H}_{2} \mathrm{O} / \mathrm{L}, 95 \% \mathrm{Cl}-0.48$ to $0.14, p<0.001$ ) and $\mathrm{FiO}_{2}$ (estimated decrease $-0.15 \%, 95 \% \mathrm{Cl}-0.23$ to $-0.06, p<0.001$ ). While $\mathrm{PaO}_{2} / \mathrm{FiO}_{2}$, was not significantly associated with static compliance of respiratory system (estimated increase $0.29 \mathrm{mmHg}, 95 \% \mathrm{Cl}-0.03$ to $0.61, p=072$ ) $\mathrm{PaO}_{2} / \mathrm{FiO}_{2}$, ratio between arterial partial pressure of oxygen and inspiratory fraction of oxygen; $\mathrm{PaCO}_{2}$ arterial partial pressure of carbon dioxide; $\mathrm{PEEP}$, positive end-expiratory pressure

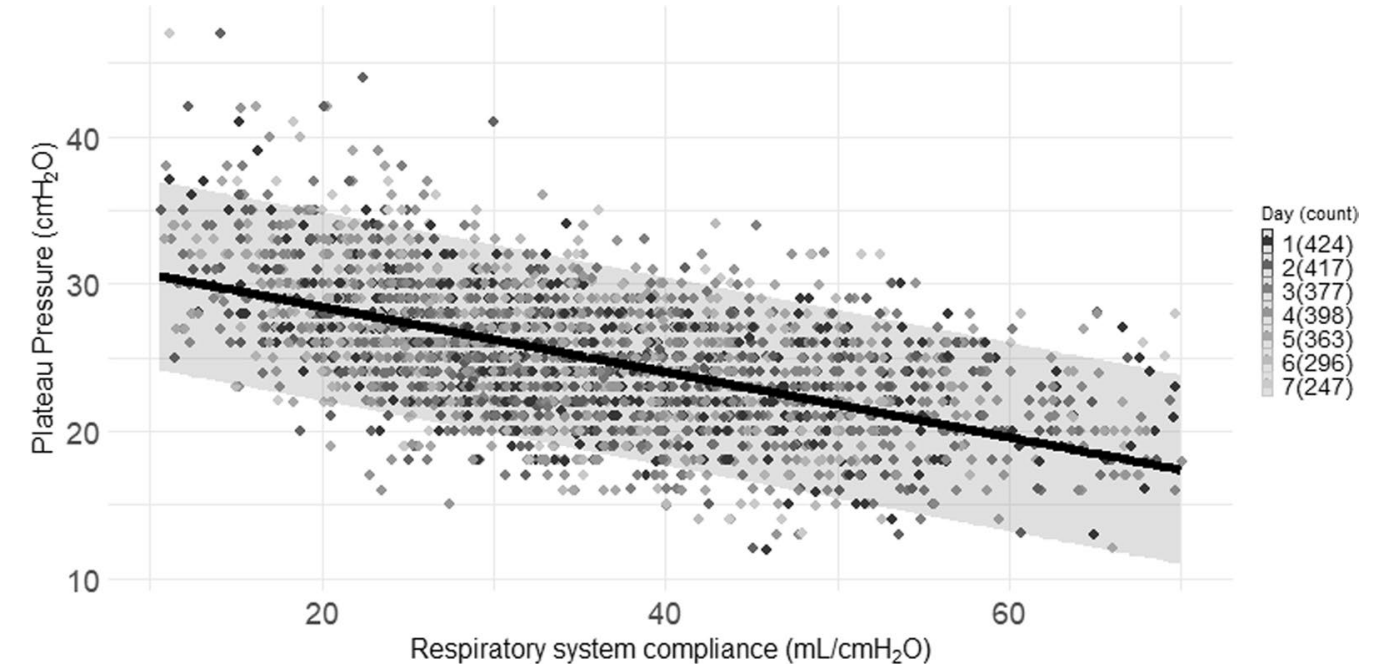

Fig. 8 Association of airway inspiratory plateau pressure with static respiratory system compliance. Linear Mixed model analysis of the association of respiratory system compliance with airway inspiratory plateau pressure during the first 7 days of mechanical ventilation (grey-scale coded bar for day 1 through 7 is reported on the right section of each graph and in parenthesis is reported the number of analysed patients). Fitted line of the model is depicted, and the upper and lower lines display the $95 \%$ predictive interval. Analysis is adjusted for body mass index. The model highlights significant association between respiratory system compliance and airway plateau pressure (estimated decrease $-0.22 \mathrm{cmH}_{2} \mathrm{O} / \mathrm{L}, 95 \% \mathrm{Cl}-0.23 \mathrm{to}$ $-0.21, p<0.001$ ), but based on the model prediction, airway plateau pressure remained predominantly below $30 \mathrm{cmH}_{2} \mathrm{O}$ 
Table 1 Only patients with the following characteristics were included in this analysis: (1) on controlled mechanical ventilation; (2) airway plateau pressure, tidal volume and positive-end-expiratory pressure recorded within $48 \mathrm{~h}$ from commencement of mechanical ventilation

\begin{tabular}{|c|c|c|}
\hline Characteristic & Full cohort $(n=745)$ & $\begin{array}{l}\text { First } C_{\mathrm{RS}} \text { recorded } \\
\text { within } 48 \mathrm{hr} \text { of } \mathrm{MV} \\
(n=649)\end{array}$ \\
\hline Age, years: $n$; median (IQR) & $745 ; 62(52-71)$ & $649 ; 62(53-71)$ \\
\hline Male: $n(\%)$ & $510(68)$ & $445(69)$ \\
\hline \multicolumn{3}{|l|}{ Geographic region: $n$ (\%) } \\
\hline Africa & $19(3)$ & $14(2)$ \\
\hline Asia & $63(8)$ & $57(9)$ \\
\hline Australia and New Zealand & $6(1)$ & $4(1)$ \\
\hline Europe & $326(44)$ & $295(45)$ \\
\hline Latin America and the Caribbean & $108(14)$ & $92(14)$ \\
\hline Northern America & $223(30)$ & $187(29)$ \\
\hline \multicolumn{3}{|l|}{ Time from onset of symptoms, days: $n$; median (IQR) } \\
\hline Onset of symptoms to hospital admission & $735 ; 7(3-9)$ & $643 ; 7(3-9)$ \\
\hline Onset of symptoms to ICU admission & $735 ; 7(5-11)$ & $643 ; 7(5-11)$ \\
\hline Onset symptoms to mechanical ventilation & $735 ; 8(5-11)$ & $643 ; 8(5-11)$ \\
\hline \multicolumn{3}{|l|}{ Clinical signs on ICU admission: $n$; median (IQR) } \\
\hline WBC count, $10^{3} / \mu \mathrm{L}$ & $604 ; 8.9(6.3-12.8)$ & $540 ; 9.0(6.6-13.0)$ \\
\hline Lymphocyte count, $10^{3}$ & $459 ; 0.7(0.5-1.1)$ & $402 ; 0.7(0.5-1.1)$ \\
\hline Temperature, ${ }^{\circ} \mathrm{C}$ & $329 ; 37.4(36.5-38.1)$ & $293 ; 37.4(36.5-38.2)$ \\
\hline Creatinine, mg/dL & $613 ; 1.0(0.7-1.4)$ & $543 ; 1.0(0.7-1.4)$ \\
\hline $\mathrm{CRP}, \mathrm{mg} / \mathrm{dL}$ & $216 ; 118.1(29.4-206.7)$ & $194 ; 121(29.1-205.6)$ \\
\hline Lymphocyte count to CRP ratio & $167 ; 0.01(0-0.03)$ & $147 ; 0.01(0-0.03)$ \\
\hline Neutrophil to Lymphocyte ratio & $414 ; 10.1(5.6-16.6)$ & $364 ; 10.2(5.9-16.6)$ \\
\hline D-dimer level mg/L & $237 ; 1.3(0.8-4.7)$ & $207 ; 1.4(0.8-4.4)$ \\
\hline \multicolumn{3}{|c|}{ Clinical management during first 28 days of ICU admission: $n$ (\%) } \\
\hline Antibiotics & $713(96)$ & $621(96)$ \\
\hline Antivirals & $288(50)$ & $245(49)$ \\
\hline Continuous renal replacement therapy & $110(15)$ & $92(15)$ \\
\hline Vasoactive drugs & $411(58)$ & $365(58)$ \\
\hline Cardiac-assist devices & $54(7)$ & $48(7)$ \\
\hline ECMO & $72(10)$ & $61(9)$ \\
\hline Prone positioning & $451(61)$ & $392(60)$ \\
\hline Inhaled nitric oxide & $72(10)$ & $66(10)$ \\
\hline Neuromuscular blockade ${ }^{a}$ & $599(81)$ & $524(81)$ \\
\hline Recruitment manoeuvres & $295(40)$ & $266(41)$ \\
\hline \multicolumn{3}{|l|}{ Clinical outcomes } \\
\hline \multicolumn{3}{|l|}{ Outcome at study end: $n(\%)$} \\
\hline Died in hospital & $300(40)$ & $266(41)$ \\
\hline Discharged alive & $400(54)$ & $339(52)$ \\
\hline Transferred to another facility & $7(1)$ & $7(1)$ \\
\hline Still in hospital/outcome not finalised & $38(5)$ & $37(6)$ \\
\hline \multicolumn{3}{|l|}{ Died in hospital } \\
\hline Duration of ICU stay, days: $n$; median (IQR) & $300 ; 12(6-20)$ & $266 ; 12(6-20)$ \\
\hline Duration of hospital stay, days: $n$, Median (IQR) & $294 ; 13(7-22)$ & $260 ; 14(7-22)$ \\
\hline Duration of MV, days: n; Median (IQR) & $300 ; 11(6-18)$ & $266 ; 11(5-18)$ \\
\hline Died within 28 days from ICU admission: $n(\%)$ & $258(86)$ & $231(87)$ \\
\hline \multicolumn{3}{|l|}{ Discharged alive } \\
\hline Duration of ICU stay, days: $n$; median (IQR) & $399 ; 19(12-30)$ & $339 ; 19(11-3)$ \\
\hline
\end{tabular}


Table 1 (continued)

\begin{tabular}{|c|c|c|}
\hline Characteristic & Full cohort $(n=745)$ & $\begin{array}{l}\text { First } C_{\mathrm{RS}} \text { recorded } \\
\text { within } 48 \mathrm{hr} \text { of } \mathrm{MV} \\
(n=649)\end{array}$ \\
\hline Duration of hospital stay, days: $n$; Median (IQR) & $396 ; 30(21-46)$ & $336 ; 30(21-45)$ \\
\hline Duration of MV, days: n; Median (IQR) & $400 ; 14(8-23)$ & $339 ; 14(8-23)$ \\
\hline Discharged alive within 28 days from ICU admission: $n(\%)$ & $195(49)$ & $165(49)$ \\
\hline
\end{tabular}

Percentages are calculated for non-missing data

$C_{R S}$, static compliance of respiratory system; CRP, c-reactive protein; $M V$, mechanical ventilation; ICU, intensive care unit; IQR, interquartile range; ECMO, extracorporeal membrane oxygenation

${ }^{\text {a }}$ Administration of neuromuscular blockade drugs administered during the first day of invasive mechanical ventilation was not included in the analysis

other injuries, while matching for similar levels of $\mathrm{PaO}_{2} /$ $\mathrm{FiO}_{2}$ [12]. Interestingly, these findings were in line with computed tomography studies results, corroborating higher proportion of normally aerated tissue in COVID19 ARDS. In similar reports, heterogeneous pathophysiology among patients with different levels of pulmonary compliance has been implied [10, 25]. As corroborated by landmark post-mortem studies [28] and clinical studies [7, 29], SARS-CoV-2 heterogeneously affects pulmonary ventilation and perfusion. Hence, it could be argued that the use of $C_{\mathrm{RS}}$ as key pathophysiological parameter to predict clinical evolution might be over simplistic and in-depth characterization of pulmonary pathophysiology should be recommended for COVID-19 patients, specifically when obese. Interestingly, our report is the first that specifically focused on the dynamics of $C_{\mathrm{RS}}$, rather than only baseline $C_{\mathrm{RS}}$. We found that $C_{\mathrm{RS}}$ was not related to the duration from the onset of symptoms to commencement of MV, emphasising the need for inclusive data on mechanisms of lung injury in not ventilated COVID-19 patients [30]. The median $C_{\mathrm{RS}}$ value found in our population was $34.1 \mathrm{~mL} / \mathrm{cmH}_{2} \mathrm{O}$, similar to findings by Ferrando et al. [6], not dissimilar to findings by Bellani et al. on patients with non-COVID-19 ARDS [31], but lower than figures recently reported by Grasselli [7] and Grieco [32] in COVID-19 patients. In addition, we found a further decrease in $C_{\mathrm{RS}}$ during the first week of MV. This could have been related to the specific ventilatory management in our reported population, but such discrepancy further highlights the need of a comprehensive appraisal of pulmonary and chest wall mechanics in COVID-19 patients [20].

One of the most striking results was the continued use of high PEEP over the first seven days of MV, even in patients with high compliance. This seems counterintuitive, given that current recommendations in ARDS suggest decreasing PEEP, especially in the face of high compliance. As hypoxemia persisted even with high PEEP and high compliance, our results add to the hypothesis that maintaining high PEEP may worsen gas exchange from lung overdistension, resulting in increased dead space and intrapulmonary shunting. Other authors have speculated that using high levels of PEEP in COVID-19 patients with low recruitability may be detrimental, and that lowering PEEP may improve gas exchange and limit ventilator-induced lung injury [33]. Our results in this large cohort of patients from multiple global areas support this theory. Finally, we found that patients required two weeks of MV, and 28-day mortality in the overall population was $35.6 \%$, with hospital mortality up to $40 \%$. These figures are in line with mortality rates reported by Grasselli [7] in the subgroups characterized by low D-dimer, and mortality in severe-moderate COVID-19 ARDS, as corroborated by Ferrando [6]. Nevertheless, we found that $C_{\mathrm{RS}}$ was only associated with the discharge from ICU within 28 days. Thus, the marginal clinical

\footnotetext{
(See figure on next page.)

Fig. 9 Multistate modelling and Cox regression analysis outcomes for patient with static compliance recorded within $48 \mathrm{~h}$ of commencing mechanical ventilation. a Multistate model structure for estimating expected outcomes up to 28 days from admission to intensive care unit (ICU). Modelled health states include not on invasive mechanical ventilation (non-MV), on mechanical ventilation (MV), ICU discharge and death. Patients start in the non-MV state if not mechanically ventilated upon or prior to ICU admission, or in the MV state otherwise. b Predicted probabilities of occupying health states up to 28 days from ICU admission. c Results of Cox proportional hazards modelling for risk of death and ICU discharge from commencement of mechanical ventilation. Covariates comprise age, body mass index (BMI), selected comorbidities (hypertension, chronic cardiac disease, chronic kidney disease) and baseline static compliance. Parameter estimates are presented as estimated hazard ratios with $95 \%$ confidence intervals (CI). Further details on factors significantly associated with assessed outcomes are available in the results section
} 
a
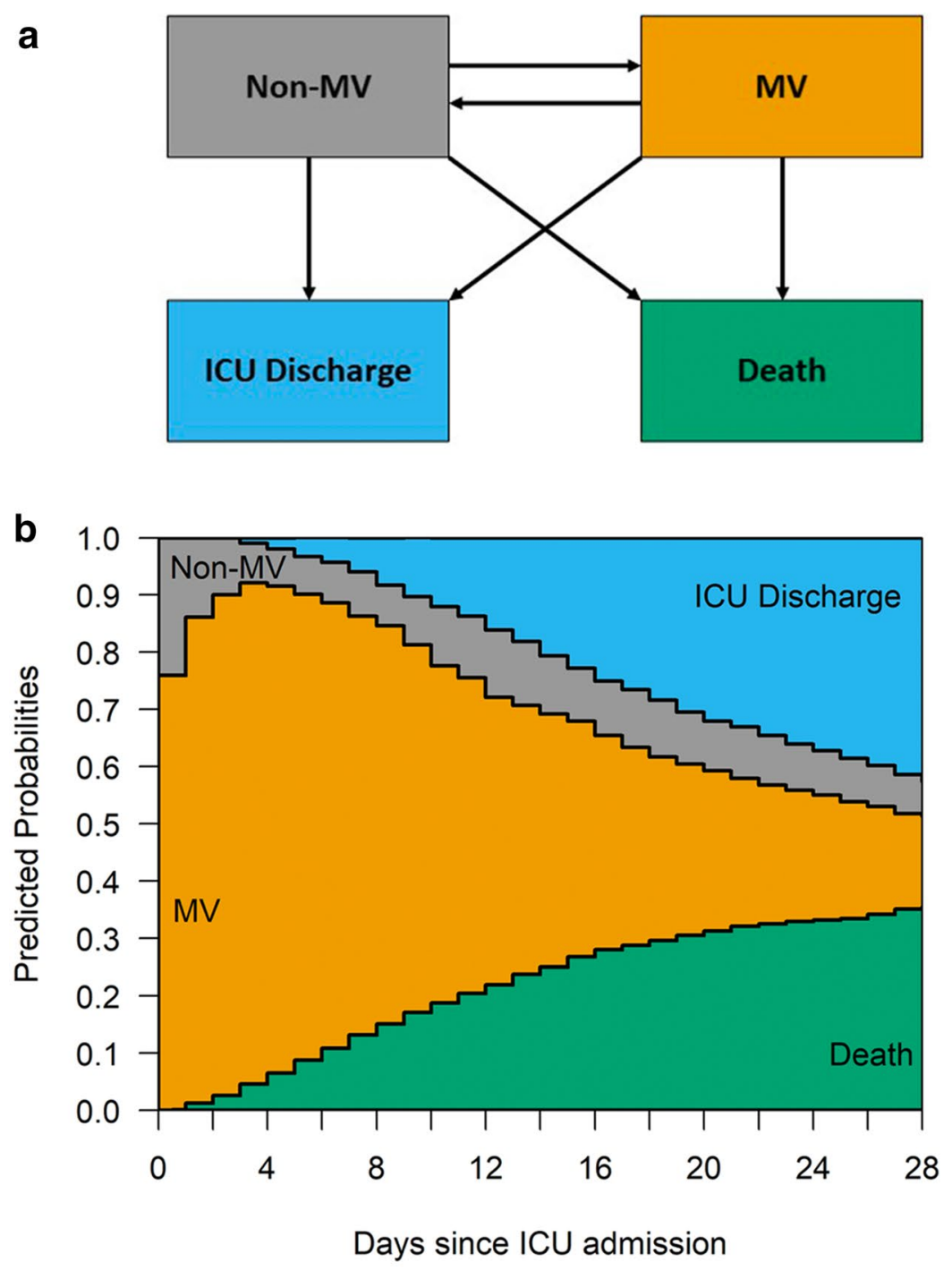

C

Respiratory system compliance (+10 mL/cmH2O)

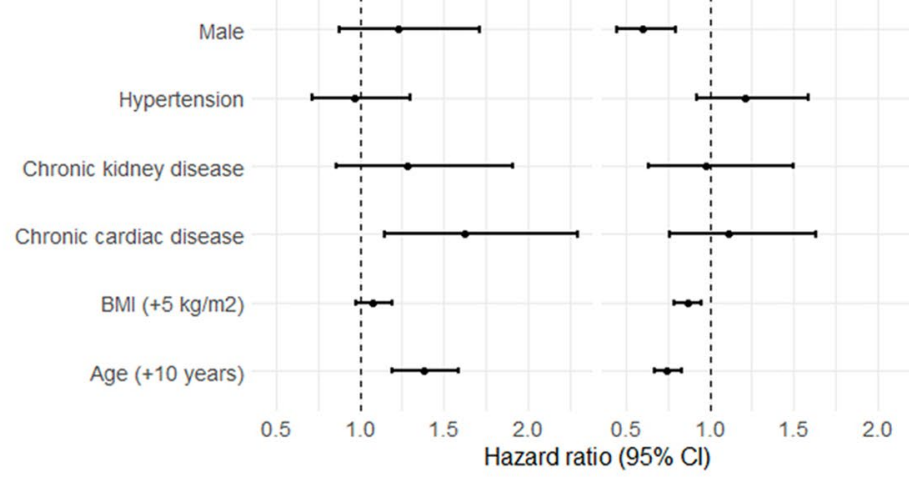


value of $C_{\mathrm{RS}}$ as a predictor of mortality in COVID-19 patients calls for urgent identification of valuable markers that could inclusively describe pulmonary derangement and guide personalized treatment.

\section{Strengths and limitations}

Collaborations between international data collection efforts have the ability to answer many questions related to COVID 19 and to pave the way for future novel diseases to achieve rapid and global data access to help guide best practice. The international COVID-19 Critical Care Consortium study [15], in collaboration with the ISARIC/SPRINT-SARI networks [34], provides inferences not limited by ventilatory management specific to small patient cohort or single-country studies. In addition, in comparison with previous studies, we provided more granular data to inclusively appraise the dynamics of $C_{\mathrm{RS}}$ in COVID-19 patients on MV and to study its association with laboratory, and clinical features. A few limitations of our observational study should also be emphasized. First, we centred our analysis on COVID-19 patients, without comparisons against previous repositories of patients with ARDS from different aetiologies. Yet, we provided a wide-ranging discussion of the characteristics of our population in the context of previous analyses in ARDS patients. Second, inferences on pulmonary perfusion disorders in our population can only be speculative, since D-dimer was only available in a small subset of patients (Table 1). Third, as reported by the enrolment rate (Fig. 1 Supplemental Digital Content), patients were mostly enrolled in the early phase of the pandemic, hence extrapolations from our findings should take into account potential biases related to overwhelmed critical care services. Fourthly, it is important to emphasise that we centred our analysis on $C_{\mathrm{RS}}$, but due to the complex respiratory pathophysiology in COVID-19 patients and the high percentage of patients with increased BMI, the use of oesophageal pressure monitoring to fully describe lung and chest wall compliances is advisable and should be prioritised in future investigations. Fifth, the majority of patients were admitted in centers located in North America, Europe and South America. Although these findings are in line with the global distribution of COVID-19 cases, extrapolations of our findings in other regions should be applied cautiously.

\section{Conclusions}

Our comprehensive appraisal of COVID-19 patients on MV from a large international observational study implies that expected $C_{\mathrm{RS}}$ within $48 \mathrm{~h}$ from commencement of $\mathrm{MV}$ is not influenced by the duration from onset of symptoms to commencement of $\mathrm{MV}$, but after intubation, a further decrease in $C_{\mathrm{RS}}$ might be expected during the first week of ventilation. In addition, baseline $C_{\mathrm{RS}}$ is associated with the chance of being discharged from the ICU within 28 days, but it is not a predictive marker of 28-day mortality. Based on potential inferences from our findings, future studies that could provide an in-depth characterization of lungs and chest wall compliance in COVID-19 patients will be critical to guide best practice in ventilatory management.

\section{Abbreviations}

ARDS: Acute respiratory distress syndrome; COVID-19: Coronavirus disease-2019; COVID-19-CCC/ECMOCARD: COVID-19 Critical Care Consortium incorporating the ExtraCorporeal Membrane Oxygenation for 2019 novel Coronavirus Acute Respiratory Disease; $\mathrm{FiO}_{2}$ : Inspiratory fraction of oxygen; ICU: Intensive care unit; IQR: Interquartile range; MV: Mechanical ventilation; PBW: Predicted body weight; PEEP: Positive end expiratory pressure; $C_{R S}$ : Static respiratory system compliance.

\section{Acknowledgements \\ We fully acknowledge statistical guidance by Adrian Barnett, Head Statisti- cian of the COVID-19 Critical Care Consortium. We recognize the crucial importance of the ISARIC and SPRINT-SARI networks for the development and expansion of the COVID-19 Critical Care Consortium. We thank the gener- ous support we received from ELSO and ECMOnet. We owe Li Wenliang, MD from the Wuhan Central Hospital an eternal debt of gratitude for reminding the world that doctors should never be censored during a pandemic. Finally, we acknowledge all members of the COVID-19 Critical Care Consortium and various collaborators.}

\section{Contributors}

\begin{tabular}{ll}
\hline Prefix/First name/Last name & Site name \\
\hline Tala Al-Dabbous & Al Adan Hospital \\
Dr Huda Alfoudri & \\
Dr Mohammed Shamsah & \\
Dr Subbarao Elapavaluru & Allegheny General Hospital \\
Ashley Berg & \\
Christina Horn & \\
Dr Stephan Schroll & Barmherzige Bruder Regansburg \\
Dr Jorge Velazco & Baylor Scott \& White Health-Tem- \\
Wanda Fikes & ple \\
Ludmyla Ploskanych & \\
Dr Dan Meyer & Baylor University Medical Centre, \\
Maysoon Shalabi-McGuire & Dallas \\
Trent Witt & \\
Ashley Ehlers & \\
Dr Lorenzo Grazioli & Bergamo Hospital \\
Dr E. Wilson Grandin & Beth Israel Deaconess Medical \\
Jose Nunez & Centre \\
Tiago Reyes & \\
\hline
\end{tabular}




\begin{tabular}{|c|c|}
\hline Prefix/First name/Last name & Site name \\
\hline $\begin{array}{l}\text { Dr Mark Joseph } \\
\text { Dr Brook Mitchell } \\
\text { Martha Tenzer }\end{array}$ & Carilion Clinic \\
\hline $\begin{array}{l}\text { Dr Ryuzo Abe } \\
\text { Yosuke Hayashi }\end{array}$ & $\begin{array}{l}\text { Chiba University Graduate School of } \\
\text { Medicine }\end{array}$ \\
\hline $\begin{array}{l}\text { Dr Hwa Jin Cho } \\
\text { Dr In Seok Jeong }\end{array}$ & $\begin{array}{l}\text { Chonnam National University } \\
\text { Hospital }\end{array}$ \\
\hline $\begin{array}{l}\text { Dr Nicolas Brozzi } \\
\text { Dr Jaime Hernandez-Montfort }\end{array}$ & Cleveland Clinic_Florida \\
\hline $\begin{array}{l}\text { Omar Mehkri } \\
\text { Stuart Houltham }\end{array}$ & Cleveland Clinic_-Ohio \\
\hline $\begin{array}{l}\text { Dr Jerónimo Graf } \\
\text { Rodrigo Perez }\end{array}$ & Clinica Alemana De Santiago \\
\hline $\begin{array}{l}\text { Dr Roderigo Diaz } \\
\text { Camila Delgado } \\
\text { Joyce González } \\
\text { Maria Soledad Sanchez }\end{array}$ & Clinica Las Condez \\
\hline $\begin{array}{l}\text { Dr Diego Fernando Bautista } \\
\text { Rincón } \\
\text { Melissa Bustamante Duque } \\
\text { Dr Angela Maria Marulanda Yanten }\end{array}$ & Clinica Valle de Lilli \\
\hline Dr Dan Brodie & Columbia University Medical Centre \\
\hline Dr Desy Rusmawatiningtyas & Dr Sardjito Hospital (Paediatrics) \\
\hline Gabrielle Ragazzo & Emory University Healthcare System \\
\hline $\begin{array}{l}\text { Dr Azhari Taufik } \\
\text { Dr Margaretha Gunawan } \\
\text { Dr Vera Irawany } \\
\text { Muhammad Rayhan } \\
\text { Dr Elizabeth Yasmin Wardoyo }\end{array}$ & Fatmawati Hospital \\
\hline $\begin{array}{l}\text { Dr Mauro Panigada } \\
\text { Dr Chiara Martinet } \\
\text { Dr Sebastiano Colombo } \\
\text { Dr Giacomo Grasselli } \\
\text { Dr Michela Leone } \\
\text { Dr Alberto Zanella }\end{array}$ & $\begin{array}{l}\text { Fondazione IRCCS Policlinico of } \\
\text { Milan (Fondazione IRCCS Ca' } \\
\text { Granda Ospedale Maggiore } \\
\text { Policlinico) }\end{array}$ \\
\hline $\begin{array}{l}\text { Prof Massimo Antonelli } \\
\text { Dr Simone Carelli } \\
\text { Domenico L. Grieco }\end{array}$ & $\begin{array}{l}\text { Fondazione Policlinico Universitario } \\
\text { Agostino Gemelli IRCCS }\end{array}$ \\
\hline Motohiro Asaki & Fujieda Municipal General Hospital \\
\hline Dr Kota Hoshino & Fukuoka University \\
\hline $\begin{array}{l}\text { Dr Leonardo Salazar } \\
\text { Laura Duarte }\end{array}$ & $\begin{array}{l}\text { Fundación Cardiovascular de } \\
\text { Colombia }\end{array}$ \\
\hline $\begin{array}{l}\text { Dr Joseph McCaffrey } \\
\text { Allison Bone }\end{array}$ & Geelong Hospital \\
\hline $\begin{array}{l}\text { Dr David Thomson } \\
\text { Dr Christel Arnold-Day } \\
\text { Jerome Cupido } \\
\text { Zainap Fanie } \\
\text { Dr Malcom Miller } \\
\text { Dr Lisa Seymore } \\
\text { Dawid van Straaten }\end{array}$ & Groote Schuur Hospital \\
\hline $\begin{array}{l}\text { Dr Ibrahim Hassan } \\
\text { Dr Ali Ait Hssain } \\
\text { Jeffrey Aliudin } \\
\text { Al-Reem Alqahtani } \\
\text { Khoulod Mohamed } \\
\text { Ahmed Mohamed } \\
\text { Darwin Tan } \\
\text { Joy Villanueva } \\
\text { Ahmed Zaqout }\end{array}$ & $\begin{array}{l}\text { Hamad General Hospital_-Weill } \\
\text { Cornell Medical College in Qatar }\end{array}$ \\
\hline
\end{tabular}

\begin{tabular}{|c|c|}
\hline Prefix/First name/Last name & Site name \\
\hline $\begin{array}{l}\text { Dr Ethan Kurtzman } \\
\text { Arben Ademi } \\
\text { Ana Dobrita } \\
\text { Khadija El Aoudi } \\
\text { Juliet Segura }\end{array}$ & Hartford HealthCare \\
\hline Dr Gezy Giwangkancana & Hasan Sadikin Hospital (Adult) \\
\hline Dr Shinichiro Ohshimo & Hiroshima University \\
\hline $\begin{array}{l}\text { Dr Koji Hoshino } \\
\text { Saito Hitoshi } \\
\text { DrYuka Uchinami }\end{array}$ & Hokkaido University Hospital \\
\hline Dr Javier Osatnik & Hospital Alemán \\
\hline Dr Anne Joosten & Hospital Civil Marie Curie \\
\hline $\begin{array}{l}\text { Dr Antoni Torres } \\
\text { Ana Motos } \\
\text { Dr Minlan Yang }\end{array}$ & Hospital Clinic, Barcelona \\
\hline Carlos Luna & Hospital de Clínicas \\
\hline Francisco Arancibia & Hospital del Tórax \\
\hline $\begin{array}{l}\text { Virginie Williams } \\
\text { Alexandre Noel }\end{array}$ & $\begin{array}{l}\text { Hospital du Sacre Coeur (Universite } \\
\text { de Montreal) }\end{array}$ \\
\hline Dr Nestor Luque & Hospital Emergencia Ate Vitarte \\
\hline $\begin{array}{l}\text { DrTrieu Huynh Trung } \\
\text { Sophie Yacoub }\end{array}$ & Hospital for Tropical Diseases \\
\hline Marina Fantini & Hospital Mater Dei \\
\hline $\begin{array}{l}\text { Dr Ruth Noemi Jorge García } \\
\text { Dr Enrique Chicote Alvarez }\end{array}$ & Hospital Nuestra Señora de Gracia \\
\hline $\begin{array}{l}\text { Dr Anna Greti } \\
\text { Oscar Lomeli }\end{array}$ & Hospital Puerta de Hierro \\
\hline Dr Adrian Ceccato & Hospital Universitari Sagrat Cor \\
\hline Dr Angel Sanchez & $\begin{array}{l}\text { Hospital Universitario Sant Joan } \\
\text { d'Alacant }\end{array}$ \\
\hline Dr Ana Loza Vazquez & $\begin{array}{l}\text { Hospital Universitario Virgen de } \\
\text { Valme }\end{array}$ \\
\hline Dr Ferran Roche-Campo & Hospital Verge de la Cinta de Tortosa \\
\hline $\begin{array}{l}\text { Dr Divina Tuazon } \\
\text { DrToni Duculan }\end{array}$ & Houston Methodist Hospital \\
\hline Hiroaki Shimizu & $\begin{array}{l}\text { Kakogawa Acute Care Medical } \\
\text { Center, Hyogo }\end{array}$ \\
\hline $\begin{array}{l}\text { Marcelo Amato } \\
\text { Luciana Cassimiro } \\
\text { Flavio Pola } \\
\text { Francis Ribeiro } \\
\text { Guilherme Fonseca }\end{array}$ & INCOR (Universidade de São Paulo) \\
\hline $\begin{array}{l}\text { Dr Heidi Dalton } \\
\text { Dr Mehul Desai } \\
\text { Dr Erik Osborn } \\
\text { Hala Deeb }\end{array}$ & INOVA Fairfax Hospital \\
\hline $\begin{array}{l}\text { Dr Antonio Arcadipane } \\
\text { Claudia Bianco } \\
\text { Raffaele Cuffaro } \\
\text { Gennaro Martucci } \\
\text { Giovanna Occhipinti } \\
\text { Matteo Rossetti } \\
\text { Chiara Vitiello }\end{array}$ & ISMETT \\
\hline $\begin{array}{l}\text { Dr Sung-Min Cho } \\
\text { Kate Calligy } \\
\text { Dr Glenn Whitman }\end{array}$ & Johns Hopkins \\
\hline $\begin{array}{l}\text { Dr Hiroaki Shimizu } \\
\text { Dr Naoki Moriyama }\end{array}$ & $\begin{array}{l}\text { Kakogawa Acute Care Medical } \\
\text { Center }\end{array}$ \\
\hline
\end{tabular}




\begin{tabular}{|c|c|c|c|}
\hline Prefix/First name/Last name & Site name & Prefix/First name/Last name & Site name \\
\hline Dr Jae-Burm Kim & $\begin{array}{l}\text { Keimyung University Dong San } \\
\text { Hospital }\end{array}$ & \multirow{2}{*}{$\begin{array}{l}\text { Dr Stephanie-Susanne Stecher } \\
\text { Delila Singh } \\
\text { Dr Michaela Barnikel } \\
\text { Lukas Arenz }\end{array}$} & \multirow[t]{2}{*}{$\begin{array}{l}\text { Medical Department II, LMU Hospi- } \\
\text { tal Munich }\end{array}$} \\
\hline $\begin{array}{l}\text { Dr Nobuya Kitamura } \\
\text { Takashi Shimazui }\end{array}$ & Kimitsu Chuo Hospital & & \\
\hline $\begin{array}{l}\text { Dr Abdullah Al-Hudaib } \\
\text { Dr Alyaa Elhazmi }\end{array}$ & $\begin{array}{l}\text { King Faisal Specialist Hospital and } \\
\text { Research Center }\end{array}$ & $\begin{array}{l}\text { Dr Akram Zaaqoq } \\
\text { Lan Anh Galloway } \\
\text { Caitlin Merley }\end{array}$ & $\begin{array}{l}\text { MedStar Washington Hospital } \\
\text { Centre }\end{array}$ \\
\hline Dr Johannes Gebauer & Klinikum Passau & \multirow{3}{*}{$\begin{array}{l}\text { Dr Marc Csete } \\
\text { Luisa Quesada } \\
\text { Isabela Saba }\end{array}$} & \multirow[t]{3}{*}{ Mount Sinai Medical Centre } \\
\hline DrToshiki Yokoyama & Kouritu Tousei Hospital & & \\
\hline \multirow{2}{*}{$\begin{array}{l}\text { Dr Abdulrahman Al-Fares } \\
\text { Esam Alamad } \\
\text { Fatma Alawadhi } \\
\text { Kalthoum Alawadi } \\
\text { Dr Sarah Buabbas }\end{array}$} & \multirow{2}{*}{$\begin{array}{l}\text { Al-Amiri and Jaber Al-Ahmed Hos- } \\
\text { pitals, Kuwait Extracorporeal Life } \\
\text { Support Program }\end{array}$} & & \\
\hline & & $\begin{array}{l}\text { Dr Daisuke Kasugai } \\
\text { Hiroaki Hiraiwa } \\
\text { Taku Tanaka }\end{array}$ & Nagoya University Hospital \\
\hline $\begin{array}{l}\text { Dr Sarah Buabbas } \\
\text { Dr Hiro Tanaka }\end{array}$ & Kyoto Medical Centre & \multirow{3}{*}{$\begin{array}{l}\text { Dr Eva Marwali } \\
\text { Yoel Purnama } \\
\text { Dr Santi Rahayu Dewayanti } \\
\text { Dr Ardiyan } \\
\text { Dr Dafsah Arifa Juzar } \\
\text { Dr Debby Siagian }\end{array}$} & \multirow[t]{3}{*}{$\begin{array}{l}\text { National Cardiovascular Center } \\
\text { Harapan Kita }\end{array}$} \\
\hline $\begin{array}{l}\text { Dr Satoru Hashimoto } \\
\text { Masaki Yamazaki }\end{array}$ & $\begin{array}{l}\text { Kyoto Prefectural University of } \\
\text { Medicine }\end{array}$ & & \\
\hline Tak-Hyuck Oh & $\begin{array}{l}\text { Kyung Pook National University } \\
\text { Chilgok Hospital }\end{array}$ & & \\
\hline \multirow{3}{*}{$\begin{array}{l}\text { Dr Mark Epler } \\
\text { Dr Cathleen Forney } \\
\text { Jared Feister } \\
\text { Katherine Grobengieser } \\
\text { Louise Kruse } \\
\text { Joelle Williamson }\end{array}$} & \multirow[t]{3}{*}{ Lancaster General Health } & Yih-Sharng Chen & National Taiwan University Hospital \\
\hline & & $\begin{array}{l}\text { Prof John Laffey } \\
\text { Dr Bairbre McNicholas } \\
\text { Dr David Cosgrave }\end{array}$ & Galway University Hospitals \\
\hline & & $\begin{array}{l}\text { Marlice VanDyk } \\
\text { Sarah MacDonald }\end{array}$ & Netcare Unitas ECMO Centre \\
\hline \multirow{4}{*}{$\begin{array}{l}\text { Dr Eric Gnall } \\
\text { Dr Mara Caroline } \\
\text { Sasha Golden } \\
\text { Colleen Karaj } \\
\text { Sherry McDermott } \\
\text { Lynn Sher } \\
\text { DrTimothy Shapiro } \\
\text { Lisa Thome } \\
\text { Mark Vanderland } \\
\text { Mary Welch }\end{array}$} & \multirow{4}{*}{$\begin{array}{l}\text { Lankenau Institute of Medical } \\
\text { Research (Main Line Health) }\end{array}$} & Dr lan Seppelt & Nepean Hospital \\
\hline & & $\begin{array}{l}\text { Dr Indrek Ratsep } \\
\text { Lauri Enneveer } \\
\text { Kristo Erikson } \\
\text { Dr Getter Oigus } \\
\text { Andra-Maris Post } \\
\text { Piret Sillaots }\end{array}$ & North Estonia Medical Centre \\
\hline & & Frank Manetta & Northwell Health \\
\hline & & Mamoru Komats & Obihiro-Kosei General Hospital \\
\hline Prof Luca Brazzi & $\begin{array}{l}\text { Le Molinette Hospital (Ospedale } \\
\text { Molinette Torino) }\end{array}$ & \multirow{5}{*}{$\begin{array}{l}\text { Dr S. Veena Satyapriya } \\
\text { Dr Amar Bhatt } \\
\text { Marco Echeverria } \\
\text { Juan Fiorda } \\
\text { Alicia Gonzalez } \\
\text { Dr Nahush A. Mokadam } \\
\text { Johnny McKeown } \\
\text { Joshua Pasek } \\
\text { Haixia Shi } \\
\text { Alberto Uribe }\end{array}$} & \multirow[t]{5}{*}{ Ohio State University Medical Centre } \\
\hline Dr Tawnya Ogston & Legacy Emanuel Medical Center & & \\
\hline $\begin{array}{l}\text { Dr Dave Nagpal } \\
\text { Karlee Fischer }\end{array}$ & London Health Sciences Centre & & \\
\hline $\begin{array}{l}\text { Dr Roberto Lorusso } \\
\text { Maria de Piero }\end{array}$ & Maastricht University Medical Centre & & \\
\hline Prof Mariano Esperatti & $\begin{array}{l}\text { Mar del Plata Medical Foundation } \\
\text { Private Community Hospital }\end{array}$ & & \\
\hline Dr Diarmuid O'Briain & Maroondah Hospital & Dr Rita Moreno & Oklahoma Heart Institute \\
\hline Dr Edmund G. Carton & $\begin{array}{l}\text { Mater Misericordiae University } \\
\text { Hospital }\end{array}$ & \multirow{2}{*}{$\begin{array}{l}\text { Bishoy Zakhary } \\
\text { Hannah Johnson } \\
\text { Nolan Pow }\end{array}$} & \multirow[t]{2}{*}{$\begin{array}{l}\text { Oregon Health and Science Univer- } \\
\text { sity Hospital (OHSU) }\end{array}$} \\
\hline Ayan Sen & \multirow[t]{2}{*}{ Mayo Clinic College of Medicine } & & \\
\hline $\begin{array}{l}\text { Amanda Palacios } \\
\text { Deborah Rainey }\end{array}$ & & $\begin{array}{l}\text { Dr Marco Cavana } \\
\text { Dr Alberto Cucino }\end{array}$ & Ospedale di Arco (Trento hospital) \\
\hline \multirow{2}{*}{$\begin{array}{l}\text { Cassandra Seefeldt } \\
\text { Dr Lucia Durham } \\
\text { Dr Octavio Falcucci } \\
\text { Amanda Emmrich } \\
\text { Jennifer Guy } \\
\text { Carling Johns } \\
\text { Emily Neumann }\end{array}$} & \multirow[t]{2}{*}{$\begin{array}{l}\text { Medical College of Wisconsin } \\
\text { (Froedtert Hospital) }\end{array}$} & $\begin{array}{l}\text { Prof Giuseppe Foti } \\
\text { Dr Marco Giani } \\
\text { Dr Vincenzo Russotto }\end{array}$ & Ospedale San Gerardo \\
\hline & & $\begin{array}{l}\text { Prof Davide Chiumello } \\
\text { Valentina Castagna } \\
\text { Silvia Coppola }\end{array}$ & Ospedale San Paolo \\
\hline $\begin{array}{l}\text { Dr Nina Buchtele } \\
\text { Dr Michael Schwameis }\end{array}$ & Medical University of Vienna & Dr Andrea Dell'Amore & $\begin{array}{l}\text { Padua University Hospital (Poli- } \\
\text { clinico of Padova) }\end{array}$ \\
\hline
\end{tabular}




\begin{tabular}{l} 
Prefix/First name/Last name \\
\hline Dr Hoi-Ping Shum \\
Dr Alain Vuysteke \\
Dr Asad Usman \\
Andrew Acker \\
Blake Mergler \\
Nicolas Rizer \\
Federico Sertic \\
Benjamin Smood \\
Alexandra Sperry \\
Dr Madhu Subramanian \\
Dr Erlina Burhan \\
Dr Navy Lolong \\
Dr Ernita Akmal \\
Prof Menaldi Rasmin \\
Bhat Naivedh \\
Dr Faya Sitompu \\
Dr Peter Barrett \\
Julia Daugherty \\
Dr David Dean \\
Dr Antonio Loforte \\
Dr Irfan Khan \\
Olivia DeSantis \\
Dr Mohammed Abraar Quraishi \\
Dr Gavin Salt \\
Dr Dominic So \\
Darshana Kandamby \\
Dr Jose M. Mandei \\
Hans Natanael \\
Eka YudhaLantang \\
Anastasia Lantang \\
Anna Jung \\
Dr Terese Hammond \\
George Ng \\
Dr Wing Yiu Ng \\
Dr Pauline Yeung \\
Dr Shingo Adachi \\
\end{tabular}

Dr Pablo Blanco

Ana Prieto

Jesús Sánchez

Dr Meghan Nicholson

Dr Michael Farquharson

DrWarwick Butt

Alyssa Serratore

Carmel Delzoppo

Dr Pierre Janin

Elizabeth Yarad

Dr Richard Totaro

Jennifer Coles

Robert Balk

Samuel Fox

James Hays

Esha Kapania

Pavel Mishin

Andy Vissing

Garrett Yantosh

\section{Site name}

Pamela Youde Nethersole Eastern Hospital

Papworth Hospitals NHS Foundation Trust

Penn Medicine (Hospital of the University of Pennsylvania)

Persahabatan General Hospital

Piedmont Atlanta Hospital

Policlinico di S. Orsola, Università di Bologna

Presbyterian Hospital Services, Albuquerque

Prince of Wales

Princess Margaret Hospital

Prof Dr R. D. Kandou General Hospital-Paediatric

Prof Dr R. D. Kandou General Hospital-Adult

Providence Saint John's Health Centre

Queen Elizabeth Hospital, Hong Kong

Queen Mary Hospital

Rinku general medical center (and Senshu trauma and critical care center)

Rio Hortega University Hospital

Rochester General Hospital

Royal Adelaide Hospital

Royal Children's Hospital

Royal North Shore Hospital

Royal Prince Alfred Hospital

Rush University, Chicago

\begin{tabular}{|c|c|}
\hline Prefix/First name/Last name & Site name \\
\hline $\begin{array}{l}\text { Saptadi Yuliarto } \\
\text { Dr Kohar Hari Santoso } \\
\text { Dr Susanthy Djajalaksana }\end{array}$ & $\begin{array}{l}\text { Saiful Anwar Malang Hospital } \\
\text { (Brawijaya University) (Paediatrics) }\end{array}$ \\
\hline Dr Arie Zainul Fatoni & $\begin{array}{l}\text { Saiful Anwar Malang Hospital } \\
\text { (Brawijaya University) (Adult) }\end{array}$ \\
\hline Dr Masahiro Fukuda & Saiseikai Senri Hospital \\
\hline Prof Keibun Liu & Saiseikai Utsunomiya Hospital \\
\hline $\begin{array}{l}\text { Prof Paolo Pelosi } \\
\text { Dr Denise Battaglini }\end{array}$ & San Martino Hospital \\
\hline Dr Juan Fernando Masa Jiménez & San Pedro de Alcantara Hospital \\
\hline $\begin{array}{l}\text { Dr Sérgio Gaião } \\
\text { Dr Roberto Roncon-Albuquerque }\end{array}$ & São João Hospital Centre, Porto \\
\hline Jessica Buchner & Sentara Norfolk General Hospital \\
\hline $\begin{array}{l}\text { Dr Young-Jae Cho } \\
\text { Dr Sang Min Lee }\end{array}$ & Seoul National University Hospital \\
\hline Dr Su Hwan Lee & Severance Hospital \\
\hline Dr Tatsuya Kawasaki & Shizuoka Children's Hospital \\
\hline $\begin{array}{l}\text { Dr Pranya Sakiyalak } \\
\text { Prompak Nitayavardhana }\end{array}$ & Siriraj Hospital \\
\hline DrTamara Seitz & $\begin{array}{l}\text { Sozialmedizinisches Zentrum Süd- } \\
\text { Kaiser-Franz-Josef-Spital }\end{array}$ \\
\hline $\begin{array}{l}\text { Rakesh Arora } \\
\text { David Kent }\end{array}$ & $\begin{array}{l}\text { St Boniface Hospital (University of } \\
\text { Mannitoba) }\end{array}$ \\
\hline $\begin{array}{l}\text { Dr Swapnil Parwar } \\
\text { Andrew Cheng } \\
\text { Jennene Miller }\end{array}$ & St George Hospital \\
\hline $\begin{array}{l}\text { Daniel Marino } \\
\text { Jillian E Deacon }\end{array}$ & $\begin{array}{l}\text { St. Christopher's Hospital for } \\
\text { Children }\end{array}$ \\
\hline $\begin{array}{l}\text { Dr Shigeki Fujitani } \\
\text { Dr Naoki Shimizu }\end{array}$ & $\begin{array}{l}\text { St Marianna Medical University } \\
\text { hospital }\end{array}$ \\
\hline $\begin{array}{l}\text { Dr Jai Madhok } \\
\text { Dr Clark Owyang }\end{array}$ & Stanford University Hospital \\
\hline $\begin{array}{l}\text { Dr Hergen Buscher } \\
\text { Claire Reynolds }\end{array}$ & St Vincent's Hospital \\
\hline $\begin{array}{l}\text { Dr Olavi Maasikas } \\
\text { Dr Aleksandr Beljantsev } \\
\text { Vladislav Mihnovits }\end{array}$ & Tartu University Hospital \\
\hline $\begin{array}{l}\text { Dr Takako Akimoto } \\
\text { Mariko Aizawa } \\
\text { Dr Kanako Horibe } \\
\text { Ryota Onodera }\end{array}$ & Teine Keijinkai Hospital \\
\hline $\begin{array}{l}\text { Prof Carol Hodgson } \\
\text { Meredith Young }\end{array}$ & The Alfred Hospital \\
\hline $\begin{array}{l}\text { Timothy Smith } \\
\text { Cheryl Bartone }\end{array}$ & The Christ Hospital \\
\hline DrTimothy George & $\begin{array}{l}\text { The Heart Hospital Baylor Plano, } \\
\text { Plano }\end{array}$ \\
\hline $\begin{array}{l}\text { Dr Kiran Shekar } \\
\text { Niki McGuinness } \\
\text { Lacey Irvine }\end{array}$ & The Prince Charles Hospital \\
\hline $\begin{array}{l}\text { Brigid Flynn } \\
\text { Abigail Houchin }\end{array}$ & $\begin{array}{l}\text { The University of Kansas Medical } \\
\text { Centre }\end{array}$ \\
\hline
\end{tabular}




\begin{tabular}{|c|c|}
\hline Prefix/First name/Last name & Site name \\
\hline $\begin{array}{l}\text { Dr Keiki Shimizu } \\
\text { Jun Hamaguchi }\end{array}$ & Tokyo Metropolitan Medical Center \\
\hline $\begin{array}{l}\text { Leslie Lussier } \\
\text { Grace Kersker } \\
\text { Dr John Adam Reich }\end{array}$ & $\begin{array}{l}\text { Tufts Medical Centre (and Floating } \\
\text { Hospital for Children) }\end{array}$ \\
\hline Dr Gösta Lotz & $\begin{array}{l}\text { Universitätsklinikum Frankfurt } \\
\text { (University Hospital Frankfurt) } \\
\text { (Uniklinik) }\end{array}$ \\
\hline $\begin{array}{l}\text { Dr Maximilian Malfertheiner } \\
\text { Esther Dreier } \\
\text { Dr Lars Maier }\end{array}$ & $\begin{array}{l}\text { Universitätsklinikum Regensburg } \\
\text { (Klinik für Innere Medizin II) }\end{array}$ \\
\hline Dr Neurinda Permata Kusumastuti & $\begin{array}{l}\text { University Airlangga Hospital } \\
\text { (Paediatric) }\end{array}$ \\
\hline $\begin{array}{l}\text { Dr Colin McCloskey } \\
\text { Dr Al-Awwab Dabaliz } \\
\text { Dr Tarek B Elshazly } \\
\text { Josiah Smith }\end{array}$ & $\begin{array}{l}\text { University Hospital Cleveland Medi- } \\
\text { cal Centre (UH Cleveland hospital) }\end{array}$ \\
\hline $\begin{array}{l}\text { Dr Konstanty S. Szuldrzynski } \\
\text { Dr Piotr Bielański }\end{array}$ & University Hospital in Krakow \\
\hline DrYusuff Hakeem & $\begin{array}{l}\text { University Hospitals of Leicester NHS } \\
\text { Trust (Glenfield Hospital) }\end{array}$ \\
\hline $\begin{array}{l}\text { Dr Keith Wille } \\
\text { Rebecca Holt }\end{array}$ & $\begin{array}{l}\text { University of Alabama at Birming- } \\
\text { ham Hospital (UAB) }\end{array}$ \\
\hline $\begin{array}{l}\text { Dr Ken Kuljit S. Parhar } \\
\text { Dr Kirsten M. Fiest } \\
\text { Cassidy Codan } \\
\text { Anmol Shahid }\end{array}$ & $\begin{array}{l}\text { University of Calgary (Peter } \\
\text { Lougheed Centre, Foothills Medi- } \\
\text { cal Centre, South Health Campus } \\
\text { and Rockyview General Hospital) }\end{array}$ \\
\hline $\begin{array}{l}\text { Dr Mohamed Fayed } \\
\text { DrTimothy Evans } \\
\text { Rebekah Garcia } \\
\text { Ashley Gutierrez } \\
\text { Hiroaki Shimizu }\end{array}$ & $\begin{array}{l}\text { University of California, San } \\
\text { Francisco-Fresno Clinical Research } \\
\text { Centre }\end{array}$ \\
\hline $\begin{array}{l}\text { DrTae Song } \\
\text { Rebecca Rose }\end{array}$ & University of Chicago \\
\hline $\begin{array}{l}\text { Dr Suzanne Bennett } \\
\text { Denise Richardson }\end{array}$ & $\begin{array}{l}\text { University of Cincinnati Medical } \\
\text { Centre }\end{array}$ \\
\hline $\begin{array}{l}\text { Dr Giles Peek } \\
\text { Dalia Lopez-Colon }\end{array}$ & University of Florida \\
\hline $\begin{array}{l}\text { Dr Lovkesh Arora } \\
\text { Kristina Rappapport } \\
\text { Kristina Rudolph } \\
\text { Zita Sibenaller } \\
\text { Lori Stout } \\
\text { Alicia Walter }\end{array}$ & University of lowa \\
\hline $\begin{array}{l}\text { Dr Daniel Herr } \\
\text { Nazli Vedadi }\end{array}$ & University of Maryland_Baltimore \\
\hline $\begin{array}{l}\text { Dr Lace Sindt } \\
\text { Cale Ewald } \\
\text { Julie Hoffman } \\
\text { Sean Rajnic } \\
\text { Shaun Thompson }\end{array}$ & $\begin{array}{l}\text { University of Nebraska Medical } \\
\text { Centre }\end{array}$ \\
\hline Dr Ryan Kennedy & $\begin{array}{l}\text { University of Oklahoma Health Sci- } \\
\text { ences Centre (OU) }\end{array}$ \\
\hline $\begin{array}{l}\text { Dr Matthew Griffee } \\
\text { Dr Anna Ciullo } \\
\text { Yuri Kida }\end{array}$ & University of Utah Hospital \\
\hline $\begin{array}{l}\text { Dr Ricard Ferrer Roca } \\
\text { Cynthia Alegre } \\
\text { Dr Sofia Contreras } \\
\text { Dr Jordl Riera }\end{array}$ & $\begin{array}{l}\text { Vall d'Hebron University Hospital, } \\
\text { Barcelona }\end{array}$ \\
\hline
\end{tabular}

\begin{tabular}{ll}
\hline Prefix/First name/Last name & Site name \\
\hline $\begin{array}{l}\text { Dr Christy Kay } \\
\text { Irene Fischer }\end{array}$ & $\begin{array}{c}\text { Washington University in St. Louis/ } \\
\text { Barnes Jewish Hospital }\end{array}$ \\
$\begin{array}{l}\text { Elizabeth Renner } \\
\text { Dr Hayato Taniguci }\end{array}$ & $\begin{array}{c}\text { Yokohama City University Medical } \\
\text { Center } \\
\text { COVID-19 Critical Care Consortium }\end{array}$ \\
Gabriella Abbate & \\
Halah Hassan & \\
Dr Silver Heinsar & \\
Varun A Karnik & \\
Dr Katrina Ki & \\
Hollier F. O'Neill & \\
Dr Nchafatso Obonyo & \\
Dr Leticia Pretti Pimenta & \\
Janice D. Reid & \\
Dr Kei Sato & \\
Dr Kiran Shekar & \\
Aapeli Vuorinen & \\
Dr Karin S. Wildi & \\
Emily S. Wood & \\
Dr Stephanie Yerkovich & \\
\hline
\end{tabular}

\section{Collaborators}

\begin{tabular}{|c|c|}
\hline Prefix/First name/Last name & Site name \\
\hline Dr Emma Hartley & $\begin{array}{l}\text { Aberdeen Royal Infirmary (Forester- } \\
\text { hill Health Campus) }\end{array}$ \\
\hline Bastian Lubis & Adam Malik Hospital \\
\hline Takanari Ikeyama & $\begin{array}{l}\text { Aichi Childrens Health and Medical } \\
\text { Center }\end{array}$ \\
\hline Balu Bhaskar & American Hospital \\
\hline Dr Jae-Seung Jung & Anam Korea University Hospital \\
\hline $\begin{array}{l}\text { Sandra Rossi Marta } \\
\text { Fabio Guarracino }\end{array}$ & $\begin{array}{l}\text { Azienda Ospedaliero Universitaria } \\
\text { Parma }\end{array}$ \\
\hline Prof Fabio Guarracino & $\begin{array}{l}\text { Azienda Ospedaliero Universitaria } \\
\text { Pisana }\end{array}$ \\
\hline Stacey Gerle & Banner University Medical Centre \\
\hline Emily Coxon & Baptist Health Louisville \\
\hline Dr Bruno Claro & Barts Hospital \\
\hline Dr. Gonzo Gonzalez-Stawinski & $\begin{array}{l}\text { Baylor All Saints Medical Centre, } \\
\text { Forth Worth }\end{array}$ \\
\hline Daniel Loverde & Billings Clinic \\
\hline Dr Vieri Parrini & Borgo San Lorenzo Hospital \\
\hline $\begin{array}{l}\text { Dr Diarmuid O'Briain } \\
\text { Stephanie Hunter }\end{array}$ & Box Hill Hospital \\
\hline Dr Angela McBride & Brighton and Sussex Medical School \\
\hline $\begin{array}{l}\text { Kathryn Negaard } \\
\text { Dr Phillip Mason }\end{array}$ & Brooke Army Medical Centre \\
\hline Dr Angela Ratsch & Bundaberg Hospital \\
\hline $\begin{array}{l}\text { Dr Mahesh Ramanan } \\
\text { Julia Affleck }\end{array}$ & Caboolture Hospital \\
\hline Ahmad Abdelaziz & Cairo University Hospital \\
\hline $\begin{array}{l}\text { Dr Sumeet Rai } \\
\text { Josie Russell-Brown } \\
\text { Mary Nourse }\end{array}$ & Canberra Hospital \\
\hline Juan David Uribe & Cardio VID \\
\hline Dr Adriano Peris & Careggi Hospital \\
\hline
\end{tabular}




\begin{tabular}{|c|c|}
\hline Prefix/First name/Last name & Site name \\
\hline Mark Sanders & Cedar Park Regional Medical Center \\
\hline Dominic Emerson & Cedars-Sinai Medical Centre \\
\hline Muhammad Kamal & Cengkareng Hospital \\
\hline Prof Pedro Povoa & Centro Hospitalar de Lisboa \\
\hline Dr Roland Francis & Charite-Univerrsitatsmedizi n Berlin \\
\hline Ali Cherif & Charles Nicolle University Hospital \\
\hline Dr Sunimol Joseph & $\begin{array}{l}\text { Children's Health Ireland (CHI) at } \\
\text { Crumlin }\end{array}$ \\
\hline Dr Matteo Di Nardo & Children's Hospital Bambino Gesù \\
\hline Micheal Heard & $\begin{array}{l}\text { Children's Healthcare of Atlanta- } \\
\text { Egleston Hospital }\end{array}$ \\
\hline Kimberly Kyle & Children's Hospital \\
\hline Ray A Blackwell & $\begin{array}{l}\text { Christiana Care Health System's Cen- } \\
\text { tre for Heart and Vascular Health }\end{array}$ \\
\hline $\begin{array}{l}\text { Dr Michael Piagnerelli } \\
\text { Dr Patrick Biston }\end{array}$ & CHU de Charleroi \\
\hline Hye Won Jeong & $\begin{array}{l}\text { Chungbuk National University } \\
\text { Hospital }\end{array}$ \\
\hline Reanna Smith & Cincinnati Children's \\
\hline Yogi Prawira & Cipto Mangunkusumo Hospital \\
\hline $\begin{array}{l}\text { Dr Giorgia Montrucchio } \\
\text { Dr Gabriele Sales }\end{array}$ & $\begin{array}{l}\text { Città della Salute e della Scienza } \\
\text { Hospital_-Turin, Italy }\end{array}$ \\
\hline $\begin{array}{l}\text { Nadeem Rahman } \\
\text { Vivek Kakar }\end{array}$ & Cleveland Clinic, Abu Dhabi \\
\hline $\begin{array}{l}\text { Dr Michael Piagnerelli } \\
\text { Dr Josefa Valenzuela Sarrazin }\end{array}$ & Clinica Las Condes \\
\hline Dr Arturo Huerta Garcia & Clínica Sagrada Família \\
\hline Dr Bart Meyns & $\begin{array}{l}\text { Collaborative Centre Department } \\
\text { Cardiac Surgery, UZ Leuven }\end{array}$ \\
\hline Marsha Moreno & $\begin{array}{l}\text { Dignity Health Medical Group- } \\
\text { Dominican }\end{array}$ \\
\hline Rajat Walia & $\begin{array}{l}\text { Dignity Health St. Joseph's Hospital } \\
\text { and Medical Center (SJHMC) }\end{array}$ \\
\hline Dr Annette Schweda & Donaustauf hospital \\
\hline Cenk Kirakli & $\begin{array}{l}\text { Dr. Suat Seren Chest Diseases and } \\
\text { Surgery Practice and Training } \\
\text { Centre }\end{array}$ \\
\hline Estefania Giraldo & $\begin{array}{l}\text { Fundación Clinica Shaio (Shaio } \\
\text { Clinic) }\end{array}$ \\
\hline Dr Wojtek Karolak & Gdansk Medical University \\
\hline Dr Martin Balik & General University Hospital \\
\hline Elizabeth Pocock & $\begin{array}{l}\text { George Washington University } \\
\text { Hospital }\end{array}$ \\
\hline Evan Gajkowski & Giesinger Medical Centre \\
\hline $\begin{array}{l}\text { Dr James Winearls } \\
\text { Mandy Tallott }\end{array}$ & Gold Coast University Hospital \\
\hline Kanamoto Masafumi & $\begin{array}{l}\text { Gunma University Graduate School } \\
\text { of Medicine }\end{array}$ \\
\hline Dr Nicholas Barrett & $\begin{array}{l}\text { Guy's and St Thomas NHS Founda- } \\
\text { tion Trust Hospital }\end{array}$ \\
\hline Yoshihiro Takeyama & Hakodate City Hospital \\
\hline Sunghoon Park & $\begin{array}{l}\text { Hallym University Sacred Heart } \\
\text { Hospital }\end{array}$ \\
\hline Faizan Amin & Hamilton General Hospital \\
\hline
\end{tabular}

\begin{tabular}{|c|c|}
\hline Prefix/First name/Last name & Site name \\
\hline Dr Erina Fina & Hasan Sadikin Hospital \\
\hline Dr Serhii Sudakevych & $\begin{array}{l}\text { Heart Institute Ministry of Health of } \\
\text { Ukraine }\end{array}$ \\
\hline Dr Angela Ratsch & Hervey Bay Hospital \\
\hline $\begin{array}{l}\text { Patrícia Schwarz } \\
\text { Ana Carolina Mardini }\end{array}$ & Hospital de Clínicas de Porto Alegre \\
\hline Ary Serpa Neto & Hospital Israelita Albert Einstein \\
\hline Dr Andrea Villoldo & Hospital Privado de Comunidad \\
\hline Alexandre Siciliano Colafranceschi & Hospital Pro Cardíaco \\
\hline Dr Alejandro Ubeda Iglesias & Hospital Punta de Europa \\
\hline $\begin{array}{l}\text { Lívia Maria Garcia Melro } \\
\text { Giovana Fioravante Romualdo }\end{array}$ & Hospital Samaritano Paulista \\
\hline Diego Gaia & Hospital Santa Catarina \\
\hline Helmgton Souza & Hospital Santa Marta \\
\hline Dr Diego Bastos & Hospital Cura D'ars Fortaleza \\
\hline Filomena Galas & Hospital Sirio Libanes \\
\hline Dr Rafael Máñez Mendiluce & Hospital Universitario de Bellvitge \\
\hline Alejandra Sosa & $\begin{array}{l}\text { Hospital Universitario Esperanza } \\
\text { (Universidad Francisco Marroquin) }\end{array}$ \\
\hline Dr lgnacio Martinez & Hospital Universitario Lucus Augusti \\
\hline Hiroshi Kurosawa & $\begin{array}{l}\text { Hyogo Prefectural Kobe Children's } \\
\text { Hospital }\end{array}$ \\
\hline Juan Salgado & Indiana University Health \\
\hline Dr Beate Hugi-Mayr & Inselspital University Hospital \\
\hline Eric Charbonneau & $\begin{array}{l}\text { Institut Universitaire de Cardiologie } \\
\text { et de Pneumologie de Quebec- } \\
\text { Universite Laval }\end{array}$ \\
\hline Vitor Salvatore Barzilai & $\begin{array}{l}\text { Instituto de Cardiologia do Distrito } \\
\text { Federal—ICDF }\end{array}$ \\
\hline Veronica Monteiro & $\begin{array}{l}\text { Instituto de Medicina Integral Prof. } \\
\text { Fernando Figueira (IMIP) }\end{array}$ \\
\hline Rodrigo Ribeiro de Souza & $\begin{array}{l}\text { Instituto Goiano de Diagnostico } \\
\text { Cardiovascular (IGDC) }\end{array}$ \\
\hline Michael Harper & INTEGRIS Baptist Medical Center \\
\hline Hiroyuki Suzuki & Japan Red Cross Maebashi Hospital \\
\hline Celina Adams & John C Lincoln Medical Centre \\
\hline Dr Jorge Brieva & John Hunter Hospital \\
\hline George Nyale & Kenyatta National Hospital (KNH) \\
\hline $\begin{array}{l}\text { Jihan Fatani } \\
\text { Dr Faisal Saleem Eltatar }\end{array}$ & $\begin{array}{l}\text { King Abdullah Medical City Special- } \\
\text { ist Hospital }\end{array}$ \\
\hline Dr. Husam Baeissa & King Abdullah Medical Complex \\
\hline Ayman AL Masri & King Salman Hospital NWAF \\
\hline Yee Hui Mok & KK Women's and Children's Hospital \\
\hline Masahiro Yamane & KKR Medical Center \\
\hline Hanna Jung & $\begin{array}{l}\text { Kyung Pook National University } \\
\text { Hospital }\end{array}$ \\
\hline $\begin{array}{l}\text { Dr Matthew Brain } \\
\text { Sarah Mineall }\end{array}$ & Launceston General Hospital \\
\hline Rhonda Bakken & M Health Fairview \\
\hline DrTim Felton & $\begin{array}{l}\text { Manchester University NHS Founda- } \\
\text { tion Trust-Wythenshawe }\end{array}$ \\
\hline Lorenzo Berra & Massachusetts General Hospital \\
\hline
\end{tabular}




\begin{tabular}{|c|c|}
\hline Prefix/First name/Last name & Site name \\
\hline $\begin{array}{l}\text { Gordan Samoukoviv } \\
\text { Dr Josie Campisi }\end{array}$ & McGill University Health Centre \\
\hline Bobby Shah & Medanta Hospital \\
\hline Arpan Chakraborty & Medica Super speciality Hospital \\
\hline Monika Cardona & Medical University of South Carolina \\
\hline Harsh Jain & Mercy Hospital of Buffalo \\
\hline Dr Asami Ito & Mie University Hospital \\
\hline Brahim Housni & Mohammed VI University hospital \\
\hline Sennen Low & $\begin{array}{l}\text { National Centre for Infectious } \\
\text { Diseases }\end{array}$ \\
\hline Dr. Koji lihara & $\begin{array}{l}\text { National Cerebral and Cardiovascu- } \\
\text { lar Center }\end{array}$ \\
\hline Joselito Chavez & $\begin{array}{l}\text { National Kidney and Transplant } \\
\text { Institute }\end{array}$ \\
\hline Dr Kollengode Ramanathan & $\begin{array}{l}\text { National University Hospital, } \\
\text { Singapore }\end{array}$ \\
\hline Gustavo Zabert & National University of Comahue \\
\hline Krubin Naidoo & Nelson Mandela Children's Hospital \\
\hline Singo Ichiba & Nippon Medical School Hospital \\
\hline Randy McGregor & Northwestern Medicine \\
\hline Teka Siebenaler & Norton Children's Hospital \\
\hline Hannah Flynn & $\begin{array}{l}\text { Novant Health (NH) Presbyterian } \\
\text { Medical Centre }\end{array}$ \\
\hline $\begin{array}{l}\text { Julia Garcia-Diaz } \\
\text { Catherine Harmon }\end{array}$ & Ochsner Clinic Foundation \\
\hline Kristi Lofton & Ochsner LSA Health Shreveport \\
\hline Toshiyuki Aokage & Okayama University Hospital \\
\hline Kazuaki Shigemitsu & Osaka City General Hospital \\
\hline Dr Andrea Moscatelli & Ospedale Gaslini \\
\hline Dr Giuseppe Fiorentino & Ospedali dei Colli \\
\hline Dr Matthias Baumgaertel & $\begin{array}{l}\text { Paracelsus Medical University } \\
\text { Nuremberg }\end{array}$ \\
\hline Serge Eddy Mba & Parirenyatwa General Hospital \\
\hline Jana Assy & $\begin{array}{l}\text { Pediatric and Neonatal Cardiac } \\
\text { intensive care at the American } \\
\text { University }\end{array}$ \\
\hline Holly Roush & $\begin{array}{l}\text { Penn State Heath S. Hershey Medi- } \\
\text { cal Centre }\end{array}$ \\
\hline Kay A Sichting & Peyton Manning Children's Hospital \\
\hline Dr Francesco Alessandri & $\begin{array}{l}\text { Policlinico Umberto, Sapienza } \\
\text { University of Rome }\end{array}$ \\
\hline Debra Burns & $\begin{array}{l}\text { Presbyterian Hospital, New York/ } \\
\text { Weill Cornell Medical Centre }\end{array}$ \\
\hline Ahmed Rabie & $\begin{array}{l}\text { Prince Mohammed bin Abdulaziz } \\
\text { Hospital }\end{array}$ \\
\hline Carl P. Garabedian & $\begin{array}{l}\text { Providence Sacred Heart Children's } \\
\text { Hospital }\end{array}$ \\
\hline $\begin{array}{l}\text { Dr Jonathan Millar } \\
\text { Dr Malcolm Sim }\end{array}$ & $\begin{array}{l}\text { Queen Elizabeth II University } \\
\text { Hospital }\end{array}$ \\
\hline Dr Adrian Mattke & Queensland Children's Hospital \\
\hline Dr Danny McAuley & Queens University of Belfast \\
\hline Jawad Tadili & Rabat university hospital \\
\hline DrTim Frenzel & Radboud University Medical Centre \\
\hline
\end{tabular}

\begin{tabular}{|c|c|}
\hline Prefix/First name/Last name & Site name \\
\hline Aaron Blandino Ortiz & Ramón y Cajal University Hospital \\
\hline Jackie Stone & Rapha Medical Centre \\
\hline $\begin{array}{l}\text { Dr Alexis Tabah } \\
\text { Megan Ratcliffe } \\
\text { Maree Duroux }\end{array}$ & Redcliffe Hospital \\
\hline Dr Antony Attokaran & Rockhampton Hospital \\
\hline Dr Brij Patel & $\begin{array}{l}\text { Royal Brompton \&Harefield NHS } \\
\text { Foundation Trust }\end{array}$ \\
\hline Derek Gunning & Royal Columbian Hospital \\
\hline Dr Kenneth Baillie & Royal Infirmary Edinburgh \\
\hline Dr Pia Watson & Sahlgrenska University Hospital \\
\hline Kenji Tamai & Saiseikai Yokohamashi Tobu Hospital \\
\hline $\begin{array}{l}\text { Dr Gede Ketut Sajinadiyasa } \\
\text { Dr Dyah Kanyawati }\end{array}$ & Sanglah General Hospital \\
\hline Marcello Salgado & $\begin{array}{l}\text { Santa Casa de Misericordia de Juiz } \\
\text { de Fora }\end{array}$ \\
\hline Assad Sassine & $\begin{array}{l}\text { Santa Casa de Misericórdia de } \\
\text { Vitoria }\end{array}$ \\
\hline Dr Bhirowo Yudo & Sardjito Hospital \\
\hline Scott McCaul & Scripps Memorial Hospital La Jolla \\
\hline Bongjin Lee & $\begin{array}{l}\text { Seoul National University Children's } \\
\text { Hospital }\end{array}$ \\
\hline Yoshiaki Iwashita & Shimane University Hospital \\
\hline Laveena munshi & $\begin{array}{l}\text { Sinai Health Systems (Mount Sinai } \\
\text { Hospital) }\end{array}$ \\
\hline Dr Neurinda Permata Kusumastuti & $\begin{array}{l}\text { Soetomo General Hospital (FK } \\
\text { UNAIR) }\end{array}$ \\
\hline Dr Nicole Van Belle & St. Antonius Hospital \\
\hline Ignacio Martin-Loeches & St James's University Hospital \\
\hline Dr Hergen Buscher & St Vincent's Hospital, Sydney \\
\hline Surya Oto Wijaya & Sulianti Saroso Hospital \\
\hline Dr Lenny Ivatt & Swansea Hospital \\
\hline Chia Yew Woon & Tan Tock Seng Hospital \\
\hline Hyun Mi Kang & $\begin{array}{l}\text { The Catholic University of Seoul St } \\
\text { Mary Hospital }\end{array}$ \\
\hline Erskine James & The Medical Centre Navicent Health \\
\hline Nawar Al-Rawas & $\begin{array}{l}\text { Thomas Jefferson University } \\
\text { Hospital }\end{array}$ \\
\hline Tomoyuki Endo & $\begin{array}{l}\text { Tohoku Medical and Pharmaceutical } \\
\text { University }\end{array}$ \\
\hline DrYudai Iwasaki & Tohoku University \\
\hline $\begin{array}{l}\text { Dr Eddy Fan } \\
\text { Kathleen Exconde }\end{array}$ & Toronto General Hospital \\
\hline Kenny Chan King-Chung & Tuen Mun Hospital \\
\hline DrVadim Gudzenko & $\begin{array}{l}\text { UCLA Medical Centre (Ronald } \\
\text { Regan) }\end{array}$ \\
\hline Dr Beate Hugi-Mayr & $\begin{array}{l}\text { Universitätsspital Bern, Universität- } \\
\text { sklinik für Herz- und Gefässchir- } \\
\text { urgie }\end{array}$ \\
\hline Dr Fabio Taccone & Universite Libre de Bruxelles \\
\hline Dr Fajar Perdhana & University Airlangga Hospital (Adult) \\
\hline Yoan Lamarche & $\begin{array}{l}\text { University de Montreal (Montreal } \\
\text { Heart Institute) }\end{array}$ \\
\hline
\end{tabular}




\begin{tabular}{ll}
\hline Prefix/First name/Last name & Site name \\
\hline Dr Joao Miguel Ribeiro & University Hospital CHLN \\
Dr Nikola Bradic & University Hospital Dubrava \\
Dr Klaartje Van den Bossche & University Hospital Leuven \\
Gurmeet Singh & University of Aberta (Mazankowski \\
& Heart Institute) \\
Dr Gerdy Debeuckelaere & University of Antwerp \\
Dr Henry T. Stelfox & University of Calgary and Alberta \\
& Health Services \\
Cassia Yi & University of California at San Diego \\
Jennifer Elia & University of California, Irvine \\
Shu Fang & University of Hong Kong \\
Thomas Tribble & University of Kentucky Medical \\
& Center \\
Shyam Shankar & University of Missouri \\
Dr Paolo Navalesi & University of Padova \\
Raj Padmanabhan & University of Pittsburgh Medical \\
Bill Hallinan & Centre \\
& University of Rochester Medical \\
Luca Paoletti & Centre (UR Medicine) \\
Yolanda Leyva & University of South Carolina \\
Tatuma Fykuda & University of Texas Medical Branch \\
Jillian Koch & University of the Ryukus \\
Amy Hackman & University of Wisconsin \& American \\
Lisa Janowaik & Family Children's Hospital \\
Jennifer Osofsky & UT Southwestern \\
A/Prof Katia Donadello & UTHealth (University of Texas) \\
Josh Fine & Vassar Brothers Medical Center \\
Dr Benjamin Davidson & (VBMC) \\
Andres Oswaldo Razo Vazquez & Verona Integrated University \\
\hline & Hospital \\
WellSpan Health-York Hospital \\
Westmead Hospital \\
& \\
& Yaven Hospital \\
\hline &
\end{tabular}

\section{Authors' contributions}

GLB conceived the study, participated in its design and coordination and helped to draft the manuscript; JYS conceived the study, participated in its design and coordination and helped to draft the manuscript drafted the manuscript; HD participated in the design of the study and helped to draft the manuscript; NW performed the statistical analysis and helped to draft the manuscript; SS participated in the coordination of the study, performed the statistical analysis and helped to draft the manuscript; JPF participated in the design of the study and helped to draft the manuscript; BL performed the statistical analysis and helped to draft the manuscript; $\mathrm{SH}$ participated in the coordination of the study performed the statistical analysis and helped to draft the manuscript; AV performed the statistical analysis and helped to draft the manuscript; GB performed the statistical analysis and helped to draft the manuscript; JEM participated in the design of the study and helped to draft the manuscript; SF participated in the design and coordination of the study and helped to draft the manuscript; MP participated in the coordination of the study helped to draft the manuscript; $J L$ participated in the coordination of the study helped to draft the manuscript; DB participated in the coordination of the study helped to draft the manuscript; EF participated in the coordination of the study helped to draft the manuscript; AT participated in the coordination of the study helped to draft the manuscript; DC participated in the coordination of the study helped to draft the manuscript; AC participated in the design of the study and helped to draft the manuscript; AE participated in collection of data and helped to draft the manuscript; $\mathrm{CH}$ participated in coordination and collection of data and helped to draft the manuscript; SI participated in collection of data and helped to draft the manuscript; $\mathrm{CL}$ participated in coordination and collection of data and helped to draft the manuscript; SM participated in coordination and collection of data and helped to draft the manuscript; AN participated in coordination and collection of data and helped to draft the manuscript; PY participated in coordination and collection of data and helped to draft the manuscript; $\mathrm{MO}$ participated in coordination and collection of data and helped to draft the manuscript; AP participated in coordination and collection of data and helped to draft the manuscript; HTT participated in collection of data and helped to draft the manuscript; JFF conceived the study, participated in its design and coordination and helped to draft the manuscript. All authors read and approved the final manuscript.

\section{Funding}

University of Queensland; Wesley Medical Research; The Prince Charles Hospital Foundation; Fisher \& Paykel; The Health Research Board of Ireland; Biomedicine international training research programme for excellent clinicianscientists; European Union's research and innovation programme (Horizon 2020); la Caixa Foundation. Finally, Carol Hodgson is funded by a National Health and Medical Research Council Grant. Sally Schrapnel is funded by the Australian Research Council Centre of Excellence for Engineered Quantum Systems (Project number CE170100009).

\section{Availability of data materials}

The datasets used and/or analysed during the current study are available from the corresponding author on reasonable request.

\section{Declarations}

\section{Ethics approval and consent to participate}

Participating hospitals obtained local ethics committee approval, and a waiver of informed consent was granted in all cases.

\section{Consent for publication}

Not applicable.

\section{Statistical analysis}

Nicole White; Sally Shrapnel; Benoit Liquet; Samuel Hinton; Aapeli Vuorinem; Gareth Booth.

\section{Competing interests}

GLB and JF received research funds, through their affiliated institution from Fisher \& Paykel. All remaining authors do not have any conflict of interest related to this report.

\section{Author details}

${ }^{1}$ Critical Care Research Group, The Prince Charles Hospital, Chermside, Australia. ${ }^{2}$ University of Queensland, Brisbane, Australia. ${ }^{3}$ Institut d'Investigacions Biomèdiques August Pi i Sunyer, Barcelona, Spain. ${ }^{4}$ Queensland University of Technology, Brisbane, Australia. ${ }^{5}$ St Andrew's War Memorial Hospital, UnitingCare Hospitals, Brisbane, Australia. ${ }^{6}$ Wesley Medical Research, Brisbane, Australia. ${ }^{7}$ INOVA Fairfax Medical Center, Heart and Vascular Institute, Falls Church, VA, USA. ${ }^{8}$ University of Pau et Pays De L'Adour, LMAP, E2S-UPPA, CNRS, Pau, France. ${ }^{9}$ Macquarie University, Sydney, Australia. ${ }^{10}$ Roslin Institute, University of Edinburgh, Edinburgh, UK. ${ }^{11}$ Queen Elizabeth II University Hospital, Glasgow, UK. ${ }^{12}$ Fondazione IRCCS Ca' Granda Ospedale Maggiore Policlinico di Milano, Milan, Italy. ${ }^{13}$ Anaesthesia and Intensive Care Medicine, National University of Ireland, Galway, Ireland. ${ }^{14}$ Department of Medicine, Columbia College of Physicians and Surgeons, and Center for Acute Respiratory Failure, New-York-Presbyterian Hospital, New York, NY, USA. ${ }^{15}$ Interdepartmental 
Division of Critical Care Medicine, University of Toronto, Toronto, Canada. ${ }^{16}$ Department of Medicine, University of Toronto, Toronto, Canada. ${ }^{17}$ Institute of Health Policy, Management and Evaluation, University of Toronto, Toronto, Canada. ${ }^{18}$ Toronto General Hospital Research Institute, University of Toronto, Toronto, Canada. ${ }^{19}$ Hospital Clinic of Barcelona, Barcelona, Spain. ${ }^{20}$ Ospedale San Paolo, Milan, Italy. ${ }^{21}$ University of Milan, Milan, Italy. ${ }^{22}$ King Faisal Specialist Hospital and Research Centre, Riyadh, Saudi Arabia. ${ }^{23}$ The Alfred Hospital, Melbourne, Australia. ${ }^{24}$ Australian and New Zealand Intensive Care Research Centre, Department of Epidemiology and Preventive Medicine, School of Public Health, Monash University, Melbourne, Australia. ${ }^{25}$ University College Dublin-Clinical Research Centre at St Vincent's University Hospital, Dublin, Ireland. ${ }^{26}$ Intensive Care, Nippon Medical School Hospital, Tokyo, Japan. ${ }^{27} \mathrm{Neu}-$ monología, Hospital de Clínicas, UBA, Buenos Aires, Argentina. ${ }^{28}$ Department of Pediatrics, Faculty of Medicine, University of British Columbia, Vancouver, Canada. ${ }^{29}$ The University of Hong Kong, Hong Kong, China. ${ }^{30}$ Nemours Alfred I duPont Hospital for Children, Wilmington, DE, USA. ${ }^{31}$ Hospital for Tropical Diseases, Ho Chi Minh City, Vietnam. ${ }^{32}$ Australian Centre for Health Services Innovation (AusHSI) and Centre for Healthcare Transformation, School of Public Health and Social Work, Queensland University of Technology (QUT), Brisbane, QLD, Australia.

Received: 2 December 2020 Accepted: 26 February 2021 Published online: 09 June 2021

\section{References}

1. Grasselli G, Zangrillo A, Zanella A, Antonelli M, Cabrini L, Castelli A, et al. Baseline characteristics and outcomes of 1591 patients infected with SARS-CoV-2 admitted to ICUs of the lombardy region, Italy. JAMA J Am Med Assoc. 2020;323:1574-81.

2. Guan W, Ni Z, Hu Y, Liang W, Ou C, He J, et al. Clinical characteristics of coronavirus disease 2019 in China. N Engl J Med. 2020;382:1708-20.

3. Richardson S, Hirsch JS, Narasimhan M, Crawford JM, McGinn T, Davidson $\mathrm{KW}$, et al. Presenting characteristics, comorbidities, and outcomes among 5700 patients hospitalized with COVID-19 in the New York City area. JAMA J Am Med Assoc. 2020;323:E1-8.

4. Karagiannidis C, Mostert C, Hentschker C, Voshaar T, Malzahn J, Schillinger $\mathrm{G}$, et al. Case characteristics, resource use, and outcomes of 10021 patients with COVID-19 admitted to 920 German hospitals: an observational study. Lancet Respir Med [Internet]. Elsevier; 2020 [cited 2020 Aug 6];0. Available from: https://linkinghub.elsevier.com/retrieve/pii/S2213 260020303167.

5. Gibson PG, Qin L, Puah SH. COVID-19 acute respiratory distress syndrome (ARDS): clinical features and differences from typical pre-COVID-19 ARDS. Med J Aust. 2020;2020:54-56.e1.

6. Ferrando C, Suarez-Sipmann F, Mellado-Artigas R, Hernández M, Gea A, Arruti $E$, et al. Clinical features, ventilatory management, and outcome of ARDS caused by COVID-19 are similar to other causes of ARDS. Intensive Care Med [Internet]. Springer; 2020 [cited 2020 Aug 13];1-12. Available from: https://doi.org/10.1007/s00134-020-06192-2.

7. Sacco F, Tonetti MT, Pizzilli G, Ranieri VM, di Radiologia Monteduro DF, Zompatori M, et al. Pathophysiology of COVID-19-associated acute respiratory distress syndrome: a multicentre prospective observational study. 2020; Available from: www.thelancet.com/respiratory.

8. Gattinoni L, Coppola S, Cressoni M, Busana M, Rossi S, Chiumello D. COVID-19 does not lead to a "Typical" acute respiratory distress syndrome. Am J Respir Crit Care Med. 2020;201:1299-300.

9. Gattinoni L, Coppola S, Cressoni M, Busana M, Chiumello D. Covid-19 does not lead to a "Typical" acute respiratory distress syndrome. Am J Respir Crit Care Med. 2020;2020:201.

10. Gattinoni L, Chiumello D, Rossi S. COVID-19 pneumonia: ARDS or not? [Internet]. Crit. Care. BioMed Central Ltd.; 2020 [cited 2020 Jun 6]. p. 154. Available from: https://doi.org/10.1186/s13054-020-02880-z

11. Schenck EJ, Hoffman K, Goyal P, Choi J, Torres L, Rajwani K, et al. Respiratory mechanics and gas exchange in COVID-19 associated respiratory failure. American Thoracic Society; 2020.

12. Chiumello D, Busana M, Coppola S, Romitti F, Formenti P, Bonifazi M, et al. Physiological and quantitative CT-scan characterization of COVID-19 and typical ARDS: a matched cohort study. Intensive Care Med [Internet].
Springer Science and Business Media Deutschland GmbH; 2020 [cited 2020 Nov 18];1-10. Available from: https://doi.org/https://doi.org/10. 1007/s00134-020-06281-2

13. Beloncle FM, Pavlovsky B, Desprez C, Fage N, Olivier PY, Asfar P, et al. Recruitability and effect of PEEP in SARS-Cov-2-associated acute respiratory distress syndrome. Ann Intensive Care. Springer; 2020;10.

14. Pan C, Chen L, Lu C, Zhang W, Xia JA, Sklar MC, et al. Lung Recruitability in SARS-CoV-2 Associated Acute Respiratory Distress Syndrome: A Singlecenter, Observational Study. Am J Respir Crit Care Med. NLM (Medline); 2020;201.

15. ECMOCARD [Internet]. [cited 2020 Jun 2]. Available from: https://www. elso.org/COVID19/ECMOCARD.aspx.

16. Network ARDS, Brower RG, Matthay MA, Morris A, Schoenfeld D, Thompson BT, et al. Ventilation with lower tidal volumes as compared with traditional tidal volumes for acute lung injury and the acute respiratory distress syndrome. The Acute Respiratory Distress Syndrome Network. N Engl J Med [Internet]. 2000;342:1301-8. Available from: http://www.ncbi. nlm.nih.gov/pubmed/10793162.

17. Hazard D, Kaier K, Von Cube M, Grodd M, Bugiera L, Lambert J, et al. Joint analysis of duration of ventilation, length of intensive care, and mortality of COVID-19 patients: A multistate approach. BMC Med Res Methodol [Internet]. BioMed Central; 2020 [cited 2020 Oct 13];20:206. Available from: https://doi.org/10.1186/s12874-020-01082-z.

18. Bellani G, Laffey JG, Pham T, Fan E, Brochard L, Esteban A, et al. Epidemiology, patterns of care, and mortality for patients with acute respiratory distress syndrome in intensive care units in 50 countries. JAMA. 2016;315:788-800.

19. Pelosi P, Caironi P, Gattinoni L. Pulmonary and extrapulmonary forms of acute respiratory distress syndrome. Semin Respir Crit Care Med. 2001;22:259-68.

20. Chiumello D, Carlesso E, Cadringher P, Caironi P, Valenza F, Polli F, et al. Lung stress and strain during mechanical ventilation for acute respiratory distress syndrome. Am J Respir Crit Care Med. 2008;178:346-55.

21. Fan E, Del Sorbo L, Goligher EC, Hodgson CL, Munshi L, Walkey AJ, et al. An official American Thoracic Society/European Society of intensive care medicine/society of critical care medicine clinical practice guideline: Mechanical ventilation in adult patients with acute respiratory distress syndrome. Am J Respir Crit Care Med [Internet]. American Thoracic Society; 2017 [cited 2020 Oct 12];195:1253-63. Available from: https:// pubmed.ncbi.nlm.nih.gov/28459336/.

22. Talmor D, Sarge T, Malhotra A, O'Donnell CR, Ritz R, Lisbon A, et al. Mechanical ventilation guided by esophageal pressure in acute lung injury. N Engl J Med. 2008;359:2095-104.

23. Marini JJ, Gattinoni L. Management of COVID-19 respiratory distress. JAMA J Am Med Assoc. 2020;323:2329-30.

24. Li X, Ma X. Acute respiratory failure in COVID-19: is it "typical" ARDS? Crit. Care. NLM (Medline); 2020. p. 198.

25. Gattinoni L, Chiumello D, Caironi P, Busana M, Romitti F, Brazzi L, et al. COVID-19 pneumonia: different respiratory treatments for different phenotypes? Intensive Care Med. Springer; 2020. p. 1.

26. Panwar R, Madotto F, Laffey JG, Van Haren FMP. Compliance Phenotypes in Early ARDS Before the COVID-19 Pandemic. Am J Respir Crit Care Med [Internet]. American Thoracic Society; 2020 [cited 2020 Oct 12]; Available from: https://pubmed.ncbi.nlm.nih.gov/32805143/.

27. Pan C, Chen L, Lu C, Zhang W, Xia JA, Sklar MC, et al. Lung recruitability in COVID-19-associated acute respiratory distress syndrome: A single-center observational study [Internet]. Am. J. Respir. Crit. Care Med. American Thoracic Society; 2020 [cited 2020 Aug 13]. p. 1294-7. Available from: https://doi.org/10.1164/rccm.202003-0527LE.

28. Ackermann M, Verleden SE, Kuehnel M, Haverich A, Welte T, Laenger F, et al. Pulmonary Vascular Endothelialitis, Thrombosis, and Angiogenesis in Covid-19. N Engl J Med [Internet]. Massachusetts Medical Society; 2020 [cited 2020 Jun 2];NEJMoa2015432. Available from: https://doi.org/10. 1056/NEJMoa2015432.

29. Lang M, Som A, Mendoza DP, Flores EJ, Reid N, Carey D, et al. Hypoxaemia related to COVID-19: vascular and perfusion abnormalities on dualenergy CT. Lancet Infect. Dis. Lancet Publishing Group; 2020.

30. Cruces P, Retamal J, Hurtado DE, Erranz B, Iturrieta P, González C, et al. A physiological approach to understand the role of respiratory effort in the progression of lung injury in SARS-CoV-2 infection [Internet]. Crit. 
Care. BioMed Central Ltd; 2020 [cited 2021 Feb 7]. p. 494. Available from: https://doi.org/10.1186/s13054-020-03197-7.

31. Bellani G, Laffey JG, Pham T, Fan E, Brochard L, Esteban A, et al. Epidemiology, Patterns of Care, and Mortality for Patients With Acute Respiratory Distress Syndrome in Intensive Care Units in 50 Countries. JAMA [Internet]. 2016;315:788. Available from: internal-pdf://0.0.13.130/Epidemiology, Patterns of Care, and Mortality for.webarchive

32. Grieco DL, Bongiovanni F, Chen L, Menga LS, Cutuli SL, Pintaudi G, et al. Respiratory physiology of COVID-19-induced respiratory failure compared to ARDS of other etiologies. Crit Care [Internet]. NLM (Medline); 2020 [cited 2020 Oct 12];24:529. Available from: https://pubmed.ncbi. nlm.nih.gov/32859264/.

33. Roesthuis $L$, van den Berg $M$, van der Hoeven $H$. Advanced respiratory monitoring in COVID-19 patients: use less PEEP! Crit Care. Springer Science and Business Media LLC; 2020;24
34. COVID-19 Clinical Research Resources · ISARIC [Internet]. [cited 2020 Oct 12]. Available from: https://isaric.tghn.org/covid-19-clinical-researchresources/.

35. Ranieri VM, Rubenfeld GD, Thompson BT, Ferguson ND, Caldwell E, Fan E, et al. Acute Respiratory Distress Syndrome. JAMA [Internet]. 2012;307:2526-33. Available from: https://doi.org/10.1001/jama.2012. 5669.

\section{Publisher's Note}

Springer Nature remains neutral with regard to jurisdictional claims in published maps and institutional affiliations.
Ready to submit your research? Choose BMC and benefit from:

- fast, convenient online submission

- thorough peer review by experienced researchers in your field

- rapid publication on acceptance

- support for research data, including large and complex data types

- gold Open Access which fosters wider collaboration and increased citations

- maximum visibility for your research: over $100 \mathrm{M}$ website views per year

At BMC, research is always in progress.

Learn more biomedcentral.com/submissions 


\section{University Library}

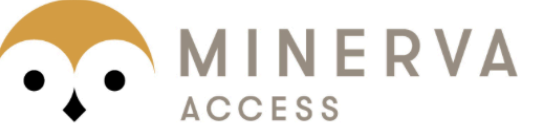

A gateway to Melbourne's research publications

Minerva Access is the Institutional Repository of The University of Melbourne

Author/s:

Li Bassi, G;Suen, JY;Dalton, HJ;White, N;Shrapnel, S;Fanning, JP;Liquet, B;Hinton,

S;Vuorinen, A;Booth, G;Millar, JE;Forsyth, S;Panigada, M;Laffey, J;Brodie, D;Fan, E;Torres, A;Chiumello, D;Corley, A;Elhazmi, A;Hodgson, C;IChiba, S;Luna, C;Murthy, S;Nichol, A;Ng, PY;Ogino, M;Pesenti, A;Trieu, HT;Fraser, JF;COVID-19 Critical Care Consortium,

Title:

An appraisal of respiratory system compliance in mechanically ventilated covid-19 patients.

Date:

2021-06-09

Citation:

Li Bassi, G., Suen, J. Y., Dalton, H. J., White, N., Shrapnel, S., Fanning, J. P., Liquet, B., Hinton, S., Vuorinen, A., Booth, G., Millar, J. E., Forsyth, S., Panigada, M., Laffey, J., Brodie, D., Fan, E., Torres, A., Chiumello, D., Corley, A. ,... COVID-19 Critical Care Consortium, (2021). An appraisal of respiratory system compliance in mechanically ventilated covid-19 patients.. Crit Care, 25 (1), pp.199-. https://doi.org/10.1186/s13054-021-03518-4.

Persistent Link:

http://hdl.handle.net/11343/296971

License:

CC BY 